\title{
Çocuk kitaplarının taşıması gereken özellikler: Cemil Kavukçu'nun Bir Öykü Yazalım Mr? ve Masal Anlatma Oyunu adlı eserlerine eleştirel bir bakış
}

İlker AYDIN1

Merve UZUN2

\begin{abstract}
APA: Aydin, I.; Uzun, M. (2020). Çocuk kitaplarının taşıması gereken özellikler: Cemil Kavukçu'nun Bir Öykü Yazalım Mr? ve Masal Anlatma Oyunu adlı eserlerine eleştirel bir bakış. RumeliDE Dil ve Edebiyat Araştırmaları Dergisi, (Ö7), 315-340. DOI: 10.29000/rumelide.808713.
\end{abstract}

\section{$\ddot{\mathbf{O} z}$}

Araştırmanın amacı edebiyatımızın önemli öykücülerinden Cemil Kavukçu'nun çocuklar için kaleme aldığı eserlerinin; çocuk kitaplarının taşıması gereken iç yapı ve dış yapı özelliklerine uygunluğunu incelemektir. Bu özellikler iç yapı ve dış yapı özellikleri olmak üzere kategorize edilmektedir. Çocuklar için hazırlanan eserlerin görsel ve dilsel nitelikleriyle, çocukların duygu ve düşünce dünyalarında istenilen etkiyi bırakabilmesi için bu özelliklere uygun olarak hazırlanması gerekir. Çocuk edebiyatı eserlerinin amaca ulaşma derecesi ile çocuk kitaplarının taşıması gereken özelliklere uygunluğu arasında doğrudan bir ilişki vardır. $\mathrm{Bu}$ nedenle incelenen eserlerin bu özelliklere uygunluğu önemlidir. Cemil Kavukçu'nun çocuk edebiyatı eserleri hakkında alan yazınında kapsamlı bir çalışma bulunmayışı da çalışmamızın gerekçelerindendir. Çalışma, nitel araştırma deseninde yürütülmüştür. Çalışmanın materyallerini yazarın, çocukların dil becerilerini geliştirmeye yönelik etkinliklere olumlu tutum kazandırabileceği ve yönlendirebileceği düşünülen Bir Öykü Yazalım Mı? ve Masal Anlatma Oyunu adlı eserleri oluşturmaktadır. Çalışmanın verileri; belgesel tarama yöntemi ile toplanmış, betimsel analizle de yorumlanmıştır. Araştırma sonucunda eserlerin çocuk kitaplarının sahip olması gereken iç yapı ve dış yapı özelliklerine uygun olduğu saptanmıştır. Ulaşılan sonuçlardan hareketle şu iki öneride bulunulmuştur: Eserlere okurun söz dağarcığını geliştirmede etkili olabileceği düşünülen bir sözlük eklenebilir. Eserlerin gerek içerik gerek biçim olarak çocuk kitaplarının taşıması gereken özelliklere uygunluğundan dolayı, yazarın eserlerine Türkçe ders kitaplarında yer verilebilir.

Anahtar kelimeler: Cemil Kavukçu, çocuk edebiyatı, çocuk kitaplarının özellikleri

\section{Features that children's books should have: A critical look at the works of Cemil Kavukçu named Bir Öykü Yazalım Mr? and Masal Anlatma Oyunu}

\begin{abstract}
The aim of the research is to study the suitability of the works of Cemil Kavukçu, one of the important storytellers of our literature, in terms of the characteristics of the internal and external structures which children's books are expected to involve. These features are categorized as internal and external structures. With the visual and linguistic qualities of the works prepared for children, it is necessary to prepare them in accordance with these features in order to leave the desired effect in the emotional and thought worlds of the children. There is a direct relationship between the

Doç. Dr., Ordu Üniversitesi, Eğitim Fakültesi, Türkçe ve Sosyal Bilimler Bölümü, Türkçe Eğitimi ABD (Ordu, Türkiye), ilkaydin67@hotmail.com, ORCID ID: oooo-0003-3369-7724 [Makale kayit tarihi: 10.07.2020-kabul tarihi: 20.10.2020; DOI: 10.29000/rumelide.808713]

YL Öğrencisi, Ordu Üniversitesi, Sosyal Bilimler Enstitüsü, Türkçe Eğitimi ABD (Ordu, Türkiye), merveuzu61@hotmail.com.tr, ORCID ID: 000o-0002-0419-3263
\end{abstract}


Features that children's books should have: A critical look at the works of Cemil Kavukçu named Bir Öykü Yazalım Mı? and Masal Anlatma Oyunu / İ. Aydın; M. Uzun (pp. 315-340)

\begin{abstract}
degree of achievement of the works of children's literature and the suitability of children's books to the characteristics expected to be involved. For this reason, the suitability of the studied works is important. The fact that Cemil Kavukçu does not have a comprehensive study in the literature about children's literature is one of the main reasons for our study. The study was carried out in a qualitative research design. The material of the study composes the works named Bir Öykü Yazalm $\mathrm{Ml}$ ? and Masal Anlatma Oyunu, which are thought to bring positive attitude towards the activities aimed at improving children's language skills. The data in the study were collected through documentary scanning method and interpreted through descriptive analysis. As a result, it was found out that the works are suitable for the internal and external structure features of children's books. Based on the conclusions reached, the following two suggestions were made: A dictionary, which is thought to be effective in improving the vocabulary of the reader, can be added to the works. Due to the suitability of the works in terms of content and form to the characteristics of children's books, the author's works can be included in Turkish textbooks.
\end{abstract}

Keywords: Cemil Kavukçu, children’s literature, characteristics of children’s books

\title{
Giriş
}

Edebiyat; duygu, düşünce ve hayallerin dille ifade edildiği bir sanattır. Anlatılmak istenenler sanatçı bakışıyla yeniden kurgulanır, insanlara estetik haz vermek amacıyla da sunulur. Sever'e (2019a, s. 31) göre dilin en etkin kullanımını edebiyatta görürüz. Şiir, roman, öykü gibi sanatçının sezme ve duyma gücünü somutlayan bu yaratılar, anlatıldığı dilin anlatım güzelliğini yansıtır. Bu metinlerin okunması; bireyi insan ve yaşam gerçekliği ile buluşturur, bireyin duygu ve düşünce evrenini genişletir. Ayrıca bu eserlerin okunması, bireyin doğrudan anlama ve anlatma becerilerini geliştirir. Edebiyat yapıtları çocuklara daha önceden deneyimlemediği yaşantıları deneyimleme imkânı verir. Bu deneyimler kurmaca bir gerçeklik vasıtasıyla gerçekleşir. Somut ve bizzat yaşanılan deneyimlerin insanı yaşama hazırlama konusunda yeterli olmayacağı gerçektir. Çocukların kurmaca bir dünya ile yaşadığı deneyimler onlara hayata hazır olma yolunda yardımcı olacaktır.

Geçmişi çok eskiye dayanmayan "çocuk edebiyatı" kavramı, 20. yüzyılın ilk yarısında ortaya çıkmıştır. Çocuk ve çocukluk kavramlarına verilen önemin artmasıyla çocuk edebiyatı da daha ön plana çıkmaya başlamıştır. Çocuk edebiyatı, 2-14 yaş çocuklarının duygu ve düşüncelerine yönelik sözlü ve yazılı tüm eserleri içine alır. Şirin'e (2019, s. 46) göre çocuk edebiyatı; edebiyatın içinde çocuğu duyarlı birey ve iyi bir okur olmaya hazırlayan bir geçiş dönemi edebiyatıdır. Çocuk edebiyatı; çocukların büyüme ve gelişmelerine, hayal, duygu ve düşünce yeteneklerine ve zevklerine hitap eden, eğitilirken eğlenmelerine katkıda bulunan yazılı ve sözlü ürünlerdir (Yalçın ve Aytaş, 2016). Cemil Meriç'e (1986) göre ise çocuk edebiyatında herhangi bir sınır bulunmamaktadır. Çocuk kavramının toplumlara ve biyolojik unsurlara göre belirsiz bir kavram olması, çocuk edebiyatının içeriğini ve sınırlarını aslında belirsiz kılmaktadır. Aynı yaş ve biyolojik evredeki çocukların, yetiştikleri ve içinde bulundukları toplum ve kültürlere göre algı seviyeleri mutlaka değişiklik gösterecektir. Bundan dolayı çocuk edebiyatının sınırları ve içeriği de farklı kültür ve toplumlara göre değişkenlik gösterecektir. Chelebourg ve Marcoin'e (2007) göre “çocuk edebiyatı” adı 1950'de eleştiri çalışmalarında ortaya çıtıt. $\mathrm{Bu}$ kavram zaman içinde yavaş yavaş gelişti ve "gençlik için edebiyat" sonra "çocukluk ve gençlik edebiyatı" son olarak "gençlik edebiyatı”na yol açtı.

Eserleri bu araştırmaya konu olan Cemil Kavukçu yetişkinler, gençler ve de çocuklar için eserler kaleme alan, Türk edebiyatına yön veren önemli öykücülerdendir. Kendinden önceki öykücülerden de 
beslenerek kendi üslubunu oluşturmuştur. Onun eserleri 80 ve 90 sonrası kuşağa ilham olmuş, dilinden ve kurgularından birçok yazar etkilenmiştir. "Ben yaşamadı̆̆ım, duyumsamadığım şeyleri yazamıyorum" (Kavukçu, 1996, s. 69) diyen yazarın eserleri, kendi hayatından ve gerçek yaşamdan izler taşır. Semih Gümüş (1999), Cemil Kavukçu'nun bir boşluğu doldurduğuna vurgu yapar. Gümüş’e göre Kavukçu, öykü severlerin beklediği öykücüdür: Farklı öykü dili, el değmemiş dünyaları, farklı tatları, anlatım yetkinliğiyle geçen kuşakların ustalarını kıskandıracak bir öykücüdür. Kavukçu, okuru etkileyen ve düşündüren öyküler yazmaktadır. Sümeyra'ya (2005, s. 69) göre ise Kavukçu, "1980 sonrası siyasal/toplumsal/edebî düzlem içerisinde Türk öykü sanatına farklı renkler, tonlar, anlayışlar kazandıran yazarlar arasındadır." Yazarın tekniği de değişkendir. Yazma noktasında, disiplinsizlik yazarın temel ilkesidir. Yaşamı doğallığı ile sunan yazar, kendine özgü bir öykü dili kurar. Uzun ve birleşik cümleler yerine kısa cümleler tercih eder. Anlatımda sıradanlığa, tekdüzeliğe de düşmez. Konuşma üslubu ile yazı üslubunu öykünün akışına göre ustalıkla kullanır (Şayak 2011, s. 7-8). Kavukçu, öykülerindeki konuşmalarda insanları kendilerine özgü dilleriyle de konuşturabilen, kendi üslubunu oluşturmuş bir yazardır. Öykülerinde şiirselliği de yakalar, ancak o bunu üslubundan ziyade yaratılan mekânlarla, kişilerle ve onların birbirleriyle olan ilişkileriyle sağlar. Şiirselliği süslü bir yazı yazarak yakalamaya çalışmanın yapaylık olacağını, okuyucuyu soğutacağını düşünür. Yazdıklarının aslında okuduklarının bir sonucu olduğunu vurgular (Karakoçan, 2007, s. 18-19). Yazar ilk gençlik romanı olan Yolun Başındakiler adlı eserinde altmışlı yılların baskıcı unsurlarını işlemiştir. Kavukçu, çocuklar için yazdığı eserlerde de hedef kitlenin ilgisini çekebilecek, onların kendinden izler bulabileceği hayatın içinden konular seçmiştir. Bu eserlerde yalın ve duru bir anlatım kendini gösterir. Çocuklar için kaleme aldığı eserlere; Yeşilcik, Havhav Kardeşliği (BOPATO 1), Özgürlüğe Kaçış (BOPATO 2), Kafeste Bir Topik (BOPATO 3), Berk’in Gizli Gücü, Selo’nun Kuşları, Bir Öykü Yazalım mı? ve Masal Kurma Oyunu örnek verilebilir.

Çocuklar için hazırlanan kitapların görsel ve dilsel nitelikleriyle, çocukların duygu ve düşünce dünyalarında istenilen etkiyi bırakabilmesi için bazı temel özellikler taşıması gerekir (Sever, 2019a, s. 120). Bu özellikler ‘iç yapı’ ve ‘dış yapı’ özellikleri olmak üzere incelenmektedir.

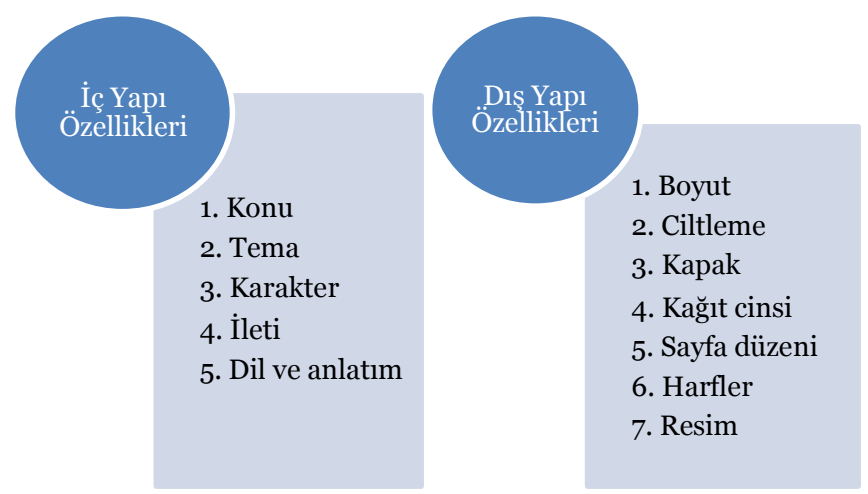

Şekil 1. Çocuk Kitaplarının Taşıması Gereken Özellikler

\section{İç yapı özellikleri}

\section{Konu}

Konu, bir edebi eserde "Ne anlatılıyor?" sorusuna verilen cevabı içerir. Konu, roman, hikâye, oyun, resim ya da filmle canlandırılan somut olaydır (Demirel, 2010, s. 55). Çocuk edebiyatında konu, 
Features that children's books should have: A critical look at the works of Cemil Kavukçu named Bir Öykü Yazahm Mı? and Masal Anlatma Oyunu / İ. Aydın; M. Uzun (pp. 315-340)

“çocuğu metnin anlam evrenine çeken, kitapla ilişkisini sağlayan ögedir" (Sever, 2019b, s. 119). Çocuk edebiyatında, seçilen konular; hedef kitlenin gelişim dönemine, ilgi ve ihtiyaçlarına uygun olmalıdır. Çocuğun her dönemde aynı ilgi, ihtiyaç ve isteklerinin olmadığı unutulmamalıdır. Çocuğun bulunduğu gelişim dönemi hakkında diğer disiplinler vasıtasıyla geniş bilgiler toplanarak çocuğa görelik ilkesi doğrultusunda konular seçilmelidir. Yalçın ve Aytaş’a (2016, s. 88) göre çocuk kitaplarının konuları, çocuğun güncel hayatı ile ilgili ve gerçeğe uygun olmalı, eserlerde çocuğun yaşadığı ortamın gerçeğine uygun mesajlar verilmelidir. Çocuk eserlerinde konu seçiminin önemi üzerinde duran Oğuzkan (2013, s. 371) ise "bu seçimde, çocukların evrensel nitelik taşıyan ruhsal özellikleri yanında, onların dünyasına ayrı bir renk ve kişilik kazandıran ulusal kültür değerlerinin, içinde yaşadıkları toplumun benimsediği ahlak kurallarının, gelenek ve göreneklerinin de göz önünde tutulması” gerektiğini vurgular. Ele alınan konular çocukları eğlendirirken düşündürmeli, onlara birtakım görüşler kazandırmalıdır. Çocuklara sağlam ve geçerli inançlar aşılayacak, onların demokratik yaşayış biçimine karşı güvenlerini artıracak, evrensel ve ulusal değerlere karşı besledikleri saygıyı daha da güçlendirecek konulara ağırlık verilmelidir. Ayrıca Oğuzkan'a (2013, s. 372) göre eserlerdeki konularda olabildiğince hareket unsuru yer almalıdır. Çünkü çocuklar bir düşünce ya da görüşün sıkça yer aldığı ve örneklerle ispatlanmaya çalışıldığı eserlerden çok, hareket unsurunun yer aldığı ve hayat durumlarının betimlendiği eserleri okumaktan hoşlanırlar. Ural'a (2013, s. 44) göre ise konu, çocuğu sürükleyecek kadar ilgi çekici, izleyebileceği kadar basit, ilgisini tutacak bir kurgu ile işlenmelidir.

Sever (2019b, s. 127), konuyu yapılandıran ögeleri 'olay örgüsü' ve 'çatışma' alt başlıkları ile ele alır. Olay örgüsü çocuğun merak duygusunu canlı tutacak ve onu okumaya çekecek nitelikte olmalıdır. Ayrıca Sever (2019b, s. 137); bir çocuk öyküsünde iyi yapılandırılmış bir konuyu, abartılmış merak, duygusallık, rastlantısallık gibi ögelerin bozabileceğini vurgular. Merak duygusu çocuğu kitap okumaya çeken ögelerin başındadır ama abartılmış merak kitabın inandırıcılığını yitirmesine neden olacağı için okuru kitaptan uzaklaştıracaktır. Başarılı bir çocuk edebiyatı eserinde abartılmış merak ve rastlantısallık çocuğun kitabı inandırıcı bulmasını engelleyecektir. İnandırıcı bulunmayan bir kitabın amacına ulaşma derecesi düşüktür. Duygusallığın eserde abartılı işlenmesi de çocuklarda hasar yaratabileceğinden, tercih edilmemelidir. Kısaca çocuk edebiyatında seçilen konular, çocuğun günlük yaşamı çevresinde kalmalı; yetişkinleri ilgilendiren düşünce, kavram ve ideolojiler henüz kendi seçimini yapamayan çocuğa aşılamaya çalışılmamalı, karamsarlık ve kötümserlik içeren konulardan uzak durulmalı, çocuğun yaşama sevincini arttırıp pekiştirecek konulara ağırlık verilmeli; çocuğa dünyayı gülerek ve düşünerek bakmayı süreç içinde duyumsatabilmelidir (Çer, 2016a, s. 145-146). Hepsinden önemlisi, edebiyat gerçeğin yeniden sunumu olduğuna göre "çocuk kitapları hangi dönemde olursa olsun yaşamın gerçeği olan konuları çocuğun dışında bırakmamalı, çocuğu gerçekle yüzleştirerek yaşama hazırlamalıdır” (Aslan, 2008; akt. Çer, 2016a, s. 147).

\section{Tema (İzlek)}

Tema ya da izlek edebi metinlerde konu üzerinden verilmek istenilen ana düşünce ya da iletidir. "Yazarın eserinde (veya yazısında) sürekli olarak belirtmeye çalıştığı temel düşünce ve görüşlere, gösterdiği ana yönelimlere 'tema (izlek)' denir” (Oğuzkan, 2013, s. 370). Temalar çocukları bilişsel ve duyuşsal yönden geliştirebilecek türden seçilmelidir. Sever'e (1995) göre tema ve konu arasında ilişki sağlam kurulmalıdır. Yazar eserin temasında politik ya da ideolojik bir güdümlülük sergilememelidir. Çocuk edebiyatının eğiticilik rolüne vurgu yapan Yalçın ve Aytaş’a (2016, s. 85) göre ise seçilen temaların, "evrensel ahlaki doğruları kazandıracak, çocuğun kişiliğini ve kimliğini geliştirerek onun toplum içinde saygın başarılı bir yere sahip olmasını sağlayacak özelliğe sahip olması gerekir.” 


\section{Karakterler}

Çocuklar okudukları kitaplardaki karakterlerle özdeşim kurma eğilimindedir. Yazar okuyucu kitleyi tanımalı ve onun özdeşim kurabileceği karakter geliştirmelidir. Karakter ne kadar iyi geliştirilirse okuyucu tarafından da o kadar inandırıcı bulunur. İnandırıcı bulunmayan karakterle özdeşim kurulma ihtimali düşüktür. Yazar birden fazla karakter geliştirme yöntemini kullanabilir. Önemli olan okuyucun inandırıcı bulacağı karakter geliştirmektir. Sever’e (2019b, s. 104) göre çocuk edebiyatında karakterler; açık karakter (geliştirilmiş) ve kapalı karakter (geliştirilmemiş) olarak iki grupta ele alınır. Çocuk edebiyatı yazarı, okuyucunun özdeşim kurabileceği iyi yapılandırılmış bir açık karakter oluşturur. Birden fazla açık karakter çocuklarda kafa karışıklığına sebep olması endişesiyle tercih edilmez. Okuyucunun bu açık karakterle onu kıyaslayama yapabileceği de bir veya birkaç kapalı karakter oluşturur. Yazar vermek istediği iletiyi bu karakterler üzerinden okuyucuya sunar. Öykü boyunca değişim gösteren geliştirilmiş karakter 'devingen (dinamik)', inandırıcı olmasına karşı değişmeyen karakteri ise 'durağan (statik)' olarak adlandırır (Sever, 2019b, s. 105). Çocuk edebiyatı eserleri çocukları yaşama hazırlama amacı da taşımaktadır. Bunu çocuğa öğüt verme yoluyla değil ona kurmaca bir yaşantı sağlayarak yapmalıdır. Karakterler aracılığıyla örtük öğrenmeler sağlanmalıdır. Devingen karakterlerin yaşadığı değişim çocuğun inandırıcı bulacağı bir şekilde sunulmalıdır. Çocuk devingen karakter ile özdeşim kurmalı ve onun değişimiyle kendine bir şey katabilmelidir.

Kitaptaki karakterle özdeşim kuran çocuk kendisini kurgunun bir parçası olarak düşünmeye başlar. Karakterin, çocuk okurun ancak düş gücüyle ulaşabileceği bazı özellikleriyle sunulması ise, çocuğun kitaba olan ilgisini daha da artırır. Başka bir deyişle çocuğun karakterlerle kurduğu iletişim, onun yeni düşsel arkadaşlar edinmesine yardımcı olur. Çocuk kendi gibi duyan, düşünen ve hareket eden başka çocuklarında olduğunun farkına varır. Ayrıca çocuk, karakterler aracılığıyla insanların başından geçebilecek olaylara tanık olur. En önemlisi de sorunlar karşısında takınacağı tavır ya da geliştireceği davranış ve stratejilere ilişkin ipuçları edinir (Çer, 2016a, s. 137). Yani çocuk okur, karakterler aracılı̆̆ıyla çok erken yaşlarda yaşanmışlık deneyimi kazanır.

\section{4. İleti (Mesaj)}

Çocuk kitaplarında ileti, kitabın yazılmasına neden olan, yazarın okurla paylaşmak istediği, temel düşünce olarak ifade edilebilir (Güleryüz, 2006, s. 163). Çocuk edebiyatı eserlerinde ileti açık, anlaşılır bir şekilde sunulmalı, belirsizliğe yer verilmemelidir. Kıbrıs'a (2010, s. 41) göre belirsizlik taşıyan kitaplar, iletinin net anlaşılmamasına neden olabilir. Çer'e (2016a, s. 153) göre yazınsal nitelikli metinlerde ileti örtüktür, yazar hiçbir zaman iletisini öğretme ve belletme amaciyla bir önerme olarak sunmaz. Çocuk, metnin içine serpiştirilen ip uçlarından yararlanarak, olaylara yönelik tahminlerde bulunarak, karakterin eylem ve davranışlarını yorumlayarak yazarın sunmuş olduğu iletilere ortak olması gerekir. Yazınsal nitelikli metinlerin iletileri genel olarak insana, yaşama ve doğaya dönük duyarlık üzerine kurulmalıdır.

\section{Dil ve anlatım}

Dil ve anlatım; eserin türünden, seslenilen hedef kitleden, yazarın üslubundan doğrudan etkilenen bir ögedir. Çocuk edebiyatı eserinin amacına ulaşabilmesi için hedef kitleye uygun dil ve anlatım seçilmelidir. Kullanılan dil çocuğun duyuşsal ve bilişsel gelişimine uygun olmalıdır. Çocukların yalın ve duru anlatımdan hoşlandıkları, günlük dilde pek kullanılmayan sözcük ve deyimleri anlamakta ve anlatmak güçlük çektikleri, uzun ve karmaşık paragrafları zor okuyup kavradıkları, yersiz benzetme ve betimlemelerden sıkıldıkları bilinmektedir (Oğuzkan, 1994; akt. Çer, 2016a, s. 150). Bu bağlamda 
Features that children's books should have: A critical look at the works of Cemil Kavukçu named Bir Öykü Yazalım Mz? and Masal Anlatma Oyunu / İ. Aydın; M. Uzun (pp. 315-340)

anlatımda gereksiz, sıradan sözcükler kullanılmamalı; edebi eserin niteliğini doğrudan etkileyen anlatım ilkelerinden açıklık, akıcılık, duruluk ve özellikle sadelik unsurlarına dikkat edilmelidir.

Eserin anlatımında seçilen kelimeler çocuğun gündelik hayatında rastladığı kelimelerden olmalıdır. Yalçın ve Aytaş'a (2016, s. 93) göre eserlerde hedef kitlenin bağlamdan hareketle anlamlandırdığı belirli sayıda bilinmeyen kelimeye yer verilmelidir. Ayrıca eserlerde kitabın sonunda bilinmeyen kelimeler için bir sözlük bulundurmalıdır. Mümkün olduğu kadar özne ve yüklemin tek olmasına özen gösterilmeli, dil zenginliğini ve ana dili kullanma alışkanlığını geliştirici bir anlatım tercih edilmeli, argo söyleyişler ile bol mecaz ve istiarelerden kaçınılmalı, çocukların kullanımda zorlandığı edat ve bağlaçlara yer verilmemelidir. Çocuklar bazen gündelik konuşmalarda bazen de edebi eserlerde eksiltili ve devrik cümlelerle karşılaşabilir. Şimşek'e (2016, s. 117) göre çocukların ilgi ve dikkati çabuk dağılabilir. Bu nedenle onlar için hazırlanmış eserlerde devrik ve sonu getirilmemiş, eksiltili cümleler çok sık ve bir arada kullanılmamalı, metin aralarına serpiştirilmelidir. Sever'e göre (1995) cümlelerde edilgen çatılı eylemler yerine etken çatılı eylemler tercih edilmelidir. Akal (2008) sinıf düzeyine göre çocuk kitaplarındaki cümlelerin özelliklerini detaylandırır. Buna göre okulöncesinde tek özneli cümleler kurulmalı, aynı cümle içerisinde birkaç kavram karıştırılmamalı ve dolaylı cümle yapısından kaçınılmalıdır. İlkokulun 1. ve 2. sınıflarında, cümleler biraz daha uzun ve dolaylı olabilir, ancak metnin bütünlüğüne yayılmadan, çok seyrek kullanılarak çocuğun daha yoğun metinlere alıştırılması sağlanabilir. Devrik cümleler de aynı seyreklikte metne yerleştirilebilir. İlköğretim 3 ve 4. sınıf evresinde, yaş grubunun sözcük ve kavram sınırları zorlanarak, bileşik cümleler kurulabilir, birkaç kavram aynı cümle içinde işlenebilir. Ancak zorlamanın tüm metne yayılmaması ve zaman zaman yoğun cümle temposu düşürülerek çocuğun metinden kopmaması sağlanmalıdır. 5. sınıf ve sonrasında, çok özneli, karmaşık ve bileşik yapıda cümleler kurulabilir; ancak burada yazar, anlatmak istediği düşünceyi okura sunmadan önce kendi zihninde çok iyi yapılandırmış olmalıdır (Akal, 2008, s. 2).

Çocuk edebiyatı eserlerinde, beş duyu organına hitap eden bir anlatımla üslup canlı kılınmalıdır. Dayıoğlu'na (1997) göre çocuk kitaplarındaki dil ve anlatımın yeni, canlı, akışkan, sapasağlam olması, gümbür gümbür soluması, çağlayan gibi coşup taşması gerekir (akt. Çer, 2016a, s. 151). Ayrıca eserlerde çocuklara dil zevki kazandırabilecek sanatlı söyleyişlere yer verilmeli; söz varlığını geliştirecek ikileme, deyim, atasözü gibi kalıplaşmış ifadeler kullanılmalıdır. Eserler, anlatımın tekdüzeliğini kıracak ve çocuğun eğlenmesini sağlayacak diğer türlerle beslenebilir. Örneğin; tekerleme, bilmece, şarkı, türkü, mektup, günlük türleri eserin anlatımında kullanılabilir. Tekerleme, bilmece, şarkı, türkü türleri çocukların eğlenme ihtiyaçlarını karşılar. Mektup ve günlük türleri hem gerçeğe çok yakın olması hem de gerçeğin bir parçasını taşıyor olması nedeniyle çocuklar tarafından ilgi çekici bulunur Ayrıca, çocuk kitaplarında yazım ve noktalama kurallarına uygun hareket edilmelidir. Bu kurallara bağlı hazırlanan kitaplar ileri yaşlarda anadilin temel ilkelerinin tam kavranması için temel oluşturur. (Yalçın ve Aytaş, 2016, s. 94). Nas’a (2004, s.87) göre de mutlaka ana dil tadı veren, dil becerisini geliştiren bir anlatım da kullanılmalıdır.

Edebi eserler farklı bakış açılarıyla kurgulanan özgün metinlerdir. Anlatımda faklı bakış açılarının yer alması, çocuğun okuma zevkini arttırdığı gibi kendi bakış açısını oluşturmasına da katkı sağlamaktadır. Edebi eserler çocuklara yaşam deneyimi de sağlamaktadır. Edebi eserler aracılı̆̆ıyla çocuklar yeni insanlar ve yerler tanır. Ayrıca yeni düşüncelerle karşı karşıya gelir. Bu da onların kendi fikirlerini oluşturması açısından önemlidir. Çer'e (2016a, s. 152) göre düzeye uygun kitapların katkısıyla dil ve anlatım becerileri gelişmiş çocuklar, duygu ve düşüncelerini etkili bir biçimde ifade ederek akran grupları arasında kendilerine yer edinebilirler. Oysa dil ve anlatım becerileri yeterince 
gelişmemiş çocuklar, kavramsal yoksunluktan dolayı kendilerini ifade etmekte zorluk yaşayabilmektedirler.

\section{Plan (Kurgu)}

Plandan; "konu, kahraman ve temanın belirli bir düzen içinde çocuk kitabına yerleştirilmesi" anlaşılmalıdır (Yalçın ve Aytaş, 2016, s. 91). Oğuzkan'a (2013, s. 373) göre dikkatle hazırlanmış bir planda eserin ana fikri açı ve net bir şekilde sunulur. Olaylar ve kahramanlar da ayrıntılar içinde kaybolmaz. Eserde gereksiz betimlemeler, konuşmalar yer almaz. Serim, düğüm, çözüm bölümleri doğal bir sıra izler. Özetle, iyi bir plan olay, duygu, düşünce ögeleri içerisinde bir uyum sağlar. Çocuk edebiyatı eserlerinde plan, çocuğun eseri kolay anlayabilmesini sağlamalıdır. Anlaşılabilirliği azaltacak anlatım teknikleri tercih edilmemelidir. Eserde kurgu neden sonuç ilişkisi içerisinde ve kafa karışıklı̆̆ına izin vermeyecek bir düzende ilerlemelidir. Aksi halde eserdeki ögeler hedef kitle tarafindan net bir şekilde anlaşılmayacaktır.

\section{Dış yapı özellikleri}

\section{Boyut}

Çocukların değişik büyüklükte kitapları karıştırmaktan ve okumaktan zevk duydukları bilinmektedir (Oğuzkan, 2013, s. 366). Sever'e (2019a, s. 121) göre çocukların ilgisini çekebilmek için çocukluğun ilk yıllarında değişik boyutlardaki kitaplar kullanılmalıdır. İlköğretimin ilk yıllarıyla beraber boyutlardaki çeşitlik, yerini düzenleme ve kitaplık oluşturma anlayışına katkı sağlayacak bir dengeye bırakmalıdır. Kitabın boyutu çocuğun rahat etkileşim kurabileceği bir şekilde oluşturulmalıdır. Ayrıca genişlik açısından kitabın iki kapağı açıldığında, çocuğun kucak boyutundan büyük olmamasına dikkat edilmelidir (Şimşek, 2016, s. 94). Çer'e (2016, s. 98) göre farklı yaş grubunda bulunan çocukların ilgileri, gereksinimleri ve bakış açıları değiştiği için kitabın boyutunun da değişmesi gerekmektedir.

\section{Ciltleme}

Şimşek'e (2016, s. 95) göre kaliteli bir cilt kitabı uzun süre kullanmayı sağlar. Ayrıca kitabın cildi kolay açılmalı ve herhangi bir destek olmadan düz bir düzeyde okunabilmelidir. Kitapların üç türlü ciltleme şekli vardır. Bunlar; sicimle ciltleme, tel zımba ile dikme, kitap formalarının tutkallama tekniği ile bir araya getirilmesidir. Tutkallama tekniği sağlam ve tercih edilen bir ciltleme tekniğidir. Çer (2016a, s. 94) dikişsiz ve ciltsiz kitapların çabuk dă̆ılıp yıpranacağına, bunun da çocukların kitaba karşı ilgisini azaltacağı gibi onların düzenli bir kitaplık kurma alışkanlı̆̆ı kazanmasını da engelleyebileceğine dikkat çeker.

\section{Kapak}

Hedef kitleyi kitaba çekecek olan ilk öge kitap kapağıdır. Kapak tasarımı ile ne kadar albenili olursa kitap okura kendini o kadar çeker. Kitapların kapağında seçilen renkler, resimler mutlaka estetik zevk vermelidir. $\mathrm{Bu}$ nedenle sanatçı duyarlılığı ile hazırlanmalıdır. Kapaklarda süsleme, kabartma kullanmak kitabın albenisini artırabilir. Kitap kapağı sağlam, çabuk yıpranmayacak malzemeden yapılmalıdır. Kapakta yıpranmayı önlemek amacıyla laklama işlemi uygulanmalıdır. Kitabın forma sayısı uygun ise sırt kısmına kitap bilgileri yerleştirilmelidir. Kitabın adı, yazarı, yayınevi bilgisinin bu kısımda yer alması kitaba çabuk ulaşabilmeyi sağlar. Ayrıca bu detay çocukların kütüphane oluşturma alışkanlığını da destekler niteliktedir. Kitabın ön ve arka kapağı gerekli bilgilerin yer aldığı detaylara 
yer vermelidir. Yazar adı, yayınevi bilgisi ve arka kapakta yer alan kitapla ilgili nitelikli bir yazı okuyucuyu kitaba yöneltebilir.

\section{Kâğıt Cinsi}

Kâğıt cinsi okuma eylemini doğrudan etkiler. Okuma eylemini olumsuz etkilemeyecek kalitede kâğıt seçilmelidir. Oğuzkan'a (2013, s. 368) göre çocuk kitaplarında kâğıt mat yani parlak olmayan cinsten olmalıdır. Bunun yanı sıra kâğıt kaliteli (en az ikinci hamur) ve dayanıklı olmalıdır. Kıbrıs (2010, s. 40) bu konuda; sayfaların kolay açılması, cilt, tutkal, dikişin sağlam olması ve okurken ışığı yansıtmaması için ikinci hamur kâğıdı veya daha az parlak birinci hamur kâğıdı önerir. Çünkü çok ince ve parlak derecede beyaz olan, üzerinde renklerin dağıldığı, bir önceki sayfanın göründüğü kağıtlar, çocuğun dilsel ve görsel okuma yapmasını engeller (Nas, 2004; Güleryüz, 2013; akt. Çer, 2016a, s. 89).

\section{Sayfa düzeni}

Sayfa üzerinde yer alan ögelerin yapisal, estetik ve kurgusal bütünlüğü ile zihinde canlanan imge arasında güçlü bir bağ vardır. Sayfadaki renk, çizgi, harf ve boşlukların oluşturduğu bütünlük, sayfada anlatılmak istenen olayı belirgin kılmaktadır (Berger, 2013; akt. Çer, 2016a, s. 99). Kıbrıs'a (2010, s. 40) göre sayfa kenarlarındaki boşluklar bir kompozisyon kâğıdı gibi planlanmalıdır. Satırlar ilk sınıflarda bir buçuk dize aralığında, ileri sınıflarda ise normal aralıklar da olmalıdır. Paragraflar 1, 2 ve 3. sinıflarda daha kısa, üç cümleyi geçmeyecek biçimde; 4 ve 5. sınıflardaysa (6-7 cümle) olmalıdır. Kitaptaki resimler de bu kurallara uygun esere yerleştirilmelidir. Oğuzkan’a (2013, s. 368) göre sayfa kenarlarında geniş boşluklar bırakılmalıdır. Şimşek'e (2016, s. 95) göre ise bu boşluklar not alınabilir şekilde planlanmalıdır. Bu gibi detaylar dikkate alınmadığında çocukların okumaya uzun süre odaklanamayacağı ve verimli bir okuma süreci gerçekleşmeyeceği düşünülmektedir. Kitapla uzun süre ve verimli bir okuma süreci gerçekleştirebilmek için bu detaylar önemsenmelidir.

\section{Harfler}

Harflerin boyutu hedef kitleye uygun olmalıdır. Harflerin yazı stili, harflerin karakteristiğini olumsuz etkilemeyecek bir stilde seçilmelidir. Tırnaksız yazı stili seçmeme harflerin okunurluğunu olumlu etkilemektedir. Yazı karakterleri ve büyüklüğü okunabilirliği etkilediğinden çocukların gelişim düzeyine göre kitaplarda uygun yazı karakterlerinin ve büyüklüğünün seçilmesi gerekir (Çer, 2016a, s. 95). Bu bağlamda, "okul öncesi dönemdeki çocuklara hitap eden kitaplarda 24, 22, 20; ilköğretimin ilk çağındaki çocuklar için hazırlanan eserlerde ise 18, 16, 14 punto boyutundaki harflerin kullanılması yeğlenmelidir" (Sever, Dilidüzgün, Neydim ve Aslan, 2009, s. 46). Gürel, Temizyürek ve Şahbaz’a (2007) göre çocuk kitaplarında harf büyüklüğü, birinci sınıf çocukları için 20-24, ikinci sınıf çocukları için 18, üçüncü sınıf çocukları için 16, dört ve beşinci sınıf çocukları için 12 puntodur (akt. Şimşek, 2106, s. 96). Yaş aralı̆̆ı ilerledikçe punto sayısında buna paralel olarak küçülmeye gidildiği bir gerçektir.

\section{Resimleme}

Özer'e (2007, s. 427) göre resim “önce bakılan, sonra görülen ve duyumsanan, daha sonra ise iletisini izleyiciye taşıyan ve bu ileti üzerinde düşündüren bir sanat” biçimidir. Estetik bir uyaran olarak çocuk kitaplarında resmin önemi yadsınamaz. Çünkü bu kitaplarda resim, hem görsel bir öge olarak kendi başına önemli bir işlev üstlenir hem de metnin anlamını tamamlar, zenginleştirir ve metne yeni anlamlar katar. Bu bağlamda resimler, sözcüklerle anlatılanı görsel olarak somutlamalı, sözcüklerin oluşturduğu anlam evrenine görsel bir yorum katmalıdır. Çocuğun beğenisini sanatsal bir dille 
okşayabilmesi, onun sürekli yeni şeyler öğrenme, tanıma gereksinimine yanıt verebilmesi için çocuk kitaplarındaki resimlerin estetik kaygı ile oluşturulması gerekir. Bu tarz resimlerin çocuğun duygu ve düşünce eğitimine de önemli katkı sağlayacağı söylenebilir. (Çer, 2016a, s. 104).

Çocuk yayınları, özellikle okul öncesi çocuklara yönelik yayınlar mutlaka resimli olmalıdır. Bu resimler yalın, açık ve konuya uygun tasarlanmalı, betimlediği olay ile aynı sayfada bulunmalı, resim ve metin bir bütün oluşturacak şekilde sayfaya yerleştirilmelidir (Oğuzkan, 2013, s. 368). Resimler çocuğun düş gücünü ve estetik algısını geliştirecek biçimde tanınmış sanatçılar tarafından çizilmeli, çocuğa neşe ve mutluluk vermelidir. Çocuk kitapları resimleyen çizer, çocuğun bilişsel ve duyuşsal gelişim aşamaları ile çocuk resimleri gelişim aşamaları arasında bağ kurmalı, renklerin çocuklar üzerindeki etkisini göz önünde bulundurmalıdır. Kitaplarda çocukların ilgisini çeken, onlarda dinamik ve neşeli bir etki yaratan sıcak renkler kullanılmalıdır. Resimler fotoğrafik bir yaklaşımla değil, çocuk bakış açısıyla çizilmeli, resimler üretilirken çocuk ruhunun doğallığının ve duyarlılı̆̆ının sınırları zorlanmamalıdır (Göknil, 2006, s. 111-112). Çocukların görsel algılarını geliştirmek için "kahramanların fiziksel portreleri, metinde yansıtılan kişilik özelliklerine uygun biçimde çizilmeli; resimler kahramanların başat özelliklerini (şişman, zayıf, uzun saçlı, kısa boylu, sinirli, uysal vb.), yaşadıkları ruhsal durumları, geçirdikleri fiziksel değişmeleri çocuklara duyumsatabilmelidir" (Sever, 2003, s. 191). Kitaplardaki resimlerle hayatta gördükleri arasındaki uyumsuzluğun, çocukta güven duygusunu sarsacağı ve olumsuz anılara dönüşebileceği göz ardı edilmemelidir. Erdal'ın betimlemesiyle "Stilizasyonlar ve deformasyonlar objenin karakteristik özelliğini bozmamalı, anlaşılırlığını kaybettirmemelidir" (Erdal, 2007, s. 405). İlkokul dönemindeki çocuklar için hazırlanan kitaplarda, oransal olarak resim ve yazı dengesi kurulmalıdır. Okuma yazma becerisinin uygulamaya dönüştüğü 8-9 yaş grubundaki çocuklara alınacak kitaplarda, üçte ikilik resim oranı yerini yazıya bırakmalı; 9-10 yaşından başlayarak çocuklara sunulacak kitaplarda, yazılı metnin oranı gittikçe artırılmalıdır (Canlı ve Aslan, 2018, s. 815). Öte yandan okunabilirlik bağlamında "yazının puntosu çocuğun yaşına uygun düzenlenmeli. Yukarı aşağı çıkıntıları büyük harflere göre daha iyi okunurluk sağladığından metinde küçük harfler kullanılmalıdır. Sayfa tasarımında yazının resim üzerine basılması düşünülüyorsa, rahat okunabilmesi için zeminle yazı arasında yeterince ton ve doku farkı olmalıdır" (Kaya, 2007, s. 422).

Çer'e (2016a, s. 107) göre çocuk kitaplarındaki resimlerin en önemli özelliği estetik değeridir. Resim dünyası bir değer oluşturmayan, baskı sırasında renklerin birbirine girip karıştığı, resimlerinde düzenleme ve desen yanlışlarının bulunduğu; sayfalarını doldurma amacıyla yapılmış, özensiz, tekdüze resimlerin yer aldığı kitaplarla öğrenciler buluşturulmamalıdır. Özünel’e (2000, s. 174) göre "görsel anlatımda yanlış yapılacağına kitap resimlenmese daha iyidir. Çünkü çocuk düş gücü ile kendi resmini kendi çizecektir.” Çocuk kitaplarına, sanatçı duyarlığının yansımasıyla oluşturulan estetik yaşantılar, çocukta bireysel duyarlı̆̆ın ve sanatsal kaygının erken dönemden başlayarak oluşturulmasına katkı sağlayabilir. Gerek tasarım gerek içerik yönünden estetik olmayan çocuk kitapları, çocuğun kalıplara dayalı, tekdüze biçimde algısının gelişmesine, bu tarz bir bakış açısı kazanmasına, üretkenlik ve hayal gücünü dışa vuramamasına neden olabilir. Çocuk kitaplarının sanatçı duyarlığıyla oluşturulması, bu kitaplara sanatsal bakış açısıyla ortaya çıkan estetik kaygının yansıması önemlidir Çer (2016b, s. 1402).

\section{Araştırmanın Amacı}

Araştırmanın amacı Cemil Kavukçu'nun seçilen eserlerinin çocuk kitaplarının taşıması gereken özelliklere göre uygunluğunu incelemektir. Alan yazınında Cemil Kavukçu'nun çocuk edebiyatı eserleri hakkında kapsamlı bir incelenme bulunmamaktadır. Bu durum da çalışmanın gerekçelerinden biridir. Araştırmanın amacı doğrultusunda aşağıdaki alt amaçlara yanıt aranmaktadır. Bu alt amaçlar şu şekildedir: 
Features that children's books should have: A critical look at the works of Cemil Kavukçu named Bir Öykü Yazalım Mı? and Masal Anlatma Oyunu / İ. Aydın; M. Uzun (pp. 315-340)

1. Eserler çocuk kitaplarının taşıması gereken “iç yapı” özelliklerine uygun mudur?

2. Eserler çocuk kitaplarının taşıması gereken “dış yapı” özelliklerine uygun mudur?

\section{Yöntem}

\section{Araștırma modeli}

Çalışma, nitel araştırma türlerinden temel nitel araştırma deseni ile yürütülmüştür. Merriam'a (2103) göre bir araştırmacı; fenomenolojik, gömülü teori, öyküsel analiz, eleştirel veya etnografik çalışma yapmadan da nitel bir çalışma yapabilmektedir. Burada temel amaç temel bir olgunun yorumlanması ve betimlenmesidir. Bu desen eğitimde sıklıkla başvurulan bir türdür. Verilerini gözlem, görüşme, gözlem ya da doküman analizi oluşturabilir.

\section{Çalışma materyali}

Araştırmada Cemil Kavukçu'nun, çocukların dil becerilerini geliştirmeye yönelik etkinliklere olumlu tutum kazandırabileceği ve yönlendirebileceği düşünülen iki eseri kullanılmıştır. Eserlerin künyesi Tablo 1'de sunulmuştur.

Tablo 1. Çalışmada Kullanılan Eserlerin Künyeleri

\begin{tabular}{lllll}
\hline Kitap Adı & Yazar & Yayınevi & Basım Yılı & Kitap Sayfası \\
Bir Öykü Yazalım Mr? & Cemil Kavukçu & Can Sanat Yayınları & 2020 (22. Baskı) & 92 \\
Masal Kurma Oyunu & Cemil Kavukçu & Can Sanat Yayınları & 2019 (6. Baskı) & 96 \\
\hline
\end{tabular}

\section{Verilerin toplanması ve analizi}

Verilerin toplanması belgesel tarama yöntemi ile yapılmıştır. Karasar'a (2020: 229) göre belgesel tarama, var olan kayıt ve belgelerden veri toplama tekniğidir. Tarananlar geçmişteki olguların iz biraktı̆̆ kayıtlardır.

Araştırmanın verileri betimsel analiz yaklaşımı ile yorumlanmıştır. Yıldırım ve Şimşek'e (2018: 239) göre betimsel analiz yaklaşımında; elde edilen veriler daha önceden belirlenen temalara göre özetlenir ve yorumlanır. Bu analizde amaç, elde edilen bulguların düzenlenmiş ve yorumlanmış bir biçimde okura sunulmasıdır. Elde edilen veriler öncelikle sistematik bir biçimde betimlenir. Daha sonra betimlemeler yorumlanıp sonuçlara ulaşılır.

Çalışmada eserler, çocuk kitaplarının taşıması gereken özelliklere göre incelenmiş, eserlerin bu özelliklere uygunluğu değerlendirilmiştir. Araştırmanın amacı doğrultusunda eserler 3 kere okunmuştur. Kaynaklar (Sever, 2019a; Sever, 2019b; Kıbrıs, 2010; Oğuzkan, 2013; Şimşek, 2016; Yalçın ve Aytaş, 2016) taranarak çocuk kitaplarının taşıması gereken özellikler tespit edilmiştir. Bulgular, çalışmanın güvenirliğini ve geçerliliğini arttırmak amacıyla incelenen eserlerdeki cümlelerden doğrudan alıntılarla birlikte sunulmuştur. 


\section{Bulgular}

\section{Bir öykü yazahm mı? adlı esere yönelik bulgular}

Kitabın Adı: Bir Öykü Yazalım Mı?

Kitabın Yazarı: Cemil Kavukçu

Resimleyen: Mustafa Delioğlu

Yaş: $9,10,11+$

\section{İç yapı özelliklerine yönelik bulgular}

\section{Konu}

Eserin konusu; küçük bir kızın öykülerini severek okuduğu bir yazarın okullarına gelip onlara deneyimlerini paylaşacağı bir söyleşi yapması haberini alması ve bu süre zarfında gerçekleşen gerçekçi olaylardır. Eserin konusu çocukların güncel hayatı ile yakından ilgilidir. Eserin hitap ettiği 9 ve üzeri yaş aralığının okul ve aile hayatında yaşadığı veya yaşaması muhtemel birçok olay esere konu edinilmiş. Çocuğun kendi gerçekliği ile örtüşebilecek bir konu seçimi yapılmıştır. Okul çağı çocuklarının yaşamlarından manzaraların devinim halinde anlatılması konuyu sıkıcı olmaktan kurtarmaktadır. Konu çocukları yazma etkinliğine teşvik edebilecek, okura bu konuda olumlu tutum kazandırabilecek türdendir.

Sever (2019b: 127) konuyu yapılandıran ögeleri “olay örgüsü” ve "çatışma” alt başlıkları ile ele alır. Eserin olay örgüsü hedef kitlenin merak duygusunu canlı tutacak niteliktedir.

Olay örgüsü 11 kesitte özetlenebilir:

1. Fatoş sevdiği öykü yazarı okula geleceği için heyecanla sabah olmasını bekler. Bu heyecanın verdiği iştahsızlıkla kahvaltısını yapar ve okula gider. Okulda yazarla ikinci kez karşılaşacaktır. Ama bu karşlaşma ilkinden daha farklı ve uzun olacaktır.

2. Yazar kendi deneyimleriyle çocuklara yol gösterebilmek amacıyla bu etkinliklere katıllyormuş. Onlara öykü yazma ve yazarlık konularında bilgi vermek istiyormuş. Fatoş da okula gelip arkadaşı Burcu ile yazarın öyküsünü tekrar okuduğunu ama buna rağmen yeniden etkilendiğini söyler. Fatoş’a göre böyle etkileyici ve canlı bir öykü anlatmanın tek yolu yaşanmış bir durumu anlatmaktır.

3. Fatoş’un sabırsızlıkla beklediği an gelmiştir. Yazar ile öğrenciler ikinci kez bir araya gelmişler. Yazar: “Öykü yazmak, yazar olmak isteyen var mı?” sorularını yöneltmiş. Soru cevap şeklinde ilerleyen bir süreçle yazar deneyimlerini ve orada olma amacını anlatmış.

4. Yazar öykü konusu olarak leyleği seçip konuşmaya devam etmiş. Fatoş, konu seçiminden önce tedirgin olmuş. Ama yazarın yönlendirici anlatımı ile bir nebze olsun sakinleşmiş. Yazar ilk önce bu öyküde neyi göreceklerini düşünmelerini istemiş. Öğrencilerden istediği cevap gelmeyince kendisi bir göl kıyısını düşünme fikrini ortaya atar. 
Features that children's books should have: A critical look at the works of Cemil Kavukçu named Bir Öykü Yazahm Mı? and Masal Anlatma Oyunu / İ. Aydın; M. Uzun (pp. 315-340)

5. Yazar, göl ve leylek üzerinden öğrencilerle sohbet ederek öykünün temel ögelerini kurgular. Ama bu sohbet sürecinde Fatoş’un aklına bir soru düşer. O da: "Bir leylek hikâyesinde diğer ögelerin (göl, yaşlı adam gibi) düşünülmesi bizi öyküden uzaklaştırmaz mı?” sorusudur. Ama bu soruyu da yazar gerekçeli bir şekilde açıklar. Fatoş sorusunun cevabının hayır olduğunu anlar.

6. Sohbet ilerledikçe öykü yaralı bir leyleğin göç yolculuğuna çıamayıp yaşlı bir adamla yolunun kesişmesi üzerine kurgulanır. Yazar bu yazı yazma sürecinde bakmak ve görmek arasındaki farkı göreceklerinden bahseder.

7. Süreç hakkında birkaç bilgilendirme daha yaparak konuşmasını bitirir. Fatoş tam bu sırada aklına takılan bir soruyu daha yazara yöneltir. Tekrar okuyup etkilendiği o öykü yaşanmış bir olayı mı anlatıyor? Sorunun cevabının hayır olması ise Fatoş'u şaşırtır. Yazar ise bu durumu yazdıkça yaşanmamış olayları yaşanmış gibi anlatmaya başlayacaksın diye açıklar.

8. Fatoş güzel geçen bir günün ardından eve döner. Ailesi onu "Leylekler Köyü" diye anılan Karaağaç köyüne götürmeye karar verir. Burada öyküsü için bilgi toplayabilme imkânı bulur. Fatoş burada Sait Dede adında yaşlı bir amca ile de karşılaşır. Ondan leylekler hakkında bilgi edinir. Fatoş Sait Dede'ye leylekler hakkında bir öykü yazacağını söyler.

9. Sait Dede de on yıl önce başından geçen yaralı bir leyleği iyileştirme hikâyesini anlatır. Lepirdek adlı leyleğin Sait Dede ile olan hikâyesi Fatoş'u çok etkiler. Sait Dede Lepirdek’in onun evinin çatısına yaptı̆̆ı yuvayı da Fatoş’a gösterir. Öyküsü için yeterince malzeme toplayan Fatoş köyden ayrılır.

10. Evde öyküye başlayan Fatoş henüz tamamlamadan annesine okutur. Ama sonra yazarın uyarısını hatırlayarak pişman olur. Yazarın yönlendirmelerine uyarak öyküsünü tamamlar.

11. Fatoş, öyküsünü öğretmeni aracıllğıyla diğer çocukların öyküleri ile beraber Yazar’a ulaştırır. Yazar öyküleri gözden geçirerek birinci olan öyküyü belirler. Daha sonra çocuklara birinciyi söylemek amaciyla okula gider. Okulda Fatoş’un öyküsü Lepirdek’i birinci seçtiğini söyler. Sürpriz olarak da bu öyküyü bir dergide yayımlayacağını söyler. Fatoş öyküsünün beğenilmesinin mutluluğu ile gülümser. Daha çok okumak ve yazmak ihtiyacı ile içi dolar.

Eserde Fatoş'un yetişkinleri zaman zaman anlayamamasından ve onlara büyüdüğünü ispat etme çabasından kaynaklanan çatışmalar birkaç yerde işlenmiştir. Bu durum kişi kişi çatışması içerisinde ele alınabilir. Konuyu zayıflatan ögeler; abartılmış merak, rastlantısallık ve duygusallık başlıklarıyla incelenir. Abartılmış merak ve olayların çözümünde sıklıkla rastlantısallıkların yer almaması eserin inandırıcılığını arttırmıştır. Çocukların duygu durumlarını olumsuz etkileyecek bir duygusallık unsuru da bulunmamaktadır. Konuyu zayıflatan ögelerden üçünün de eserde yer almaması konunun yapılanmasını güçlendirmiştir.

\section{Tema (İzlek)}

Çocuk edebiyatının temel işlevlerinden biri de okuma ve yazma alışkanlığı kazanan bireyler yetiştirmektir. Eserin temaları, çocukları bilişsel ve duyuşsal yönden besleyecek türdendir. Tema; okuma ve yazma becerilerinin ve hayal gücünün önemi olarak kabul edilebilir. Eserde alt tema olarak da ailenin önemi, aile sevgisi işlenmiştir. Eserde seçilen tema çocukları yazma ve okuma alışkanlıklarına olumlu bir bakış sağlayacak ve onları bunlara yöneltebilecek şekilde seçilmiştir. Konu 
ve tema arasında sağlam ve birbirini tamamlayan bir bağ kurulmuştur. Yazar eserin temasında politik veya ideolojik bir güdümlülük sergilememiştir.

\section{Karakterler}

Yazar hedef kitlenin yabancı olmadığı karakterler geliştirmiştir. Okuyucu, kendisini veya çevresindeki arkadaşlarından herhangi birini eserdeki karakterlerde rahatlıkla görebilir. Karakterlerin davranışları, bulunduğu çevre, diyalogları, sorunları hedef kitlenin (9 ve üzeri yaş aralığının) kendinde görebileceği izler taşımaktadır. Eserde yalnızca bir açık karakter bulunmaktadır. Bu da eserin başkahramanı Fatoş'tur. Çocuk eserlerinde kafa karışıklığı yaratmamak için tek açık karakter tercih edilmesi detayına uyulmuştur. Karakter, ağırlıklı olarak davranış ve konuşmalar yoluyla geliştirilmiş̧tir. Açıı karakter başarılı bir şekilde yapılandırılmıştır. Okuyucuyu gereksiz detaylarda boğmadan karakteri tanınmasına yetecek kadar bilgi verilmiştir. Karakter hedef kitle açısından özdeşim kurulabilecek bir karakterdir. O yaş aralığında bir kız çocuğunun; ailesiyle yaşadığı çatışmalar, davranışları bir bütün halinde inandırıcı bir biçimde sunulmuştur. Fatoş'un oyuncağı ile konuşma alışkanlığının olması ama bunun oyun olduğunun farkında olması bu yaş aralığında sık rastlanan bir durumdur. Piaget'in gelişim dönemleri bağlamında düşünülürse; Fatoş bir önceki dönemindeki animizim alışkanlığını devam ettiriyor. Ama somut dönemde olduğu için de bunun bir oyun olduğunun farkındadır. Fatoş'un davranışlarında yaşının özelliklerini sergilemesi karakterin yapılandırılmasındaki başarıyı gösterir. $\mathrm{Bu}$ da yazarın başarısıdır.

Eserde kapalı karakter kadrosu geniştir. Bunlar; Fatoş'un annesi, babası, anneannesi, okul arkadaşları ve Sait Dede'dir. Yeteri kadar bilgi verilen başarılı bir kapalı karakter kadrosu oluşturulmuştur. Eserdeki Yazar karakteri de kapalı karakter kategorisine ekleyebiliriz. Ama bu karakter yer yer açı karakter özelliği de sergilemektedir. Yazar karakteri çocuklara yazar olabilme hakkında yönlendirici iletiler vermektedir. Geleceğin yazarları olacak çocukların kaçının gerçek bir yazarla daha o yaşta tanışabilme şansına eriştiği tartışma konusudur. Ama bu karakterle kurmaca bir gerçeklik vasıtasıyla da olsa çocukların yolu gerçek bir yazarla kesişmiştir. Okura yazarın deneyim ve tecrübelerinden yararlanılabilecek başarılı bir kurgu oluşturulmuştur.

Yazarın vermek istediği iletileri devingen karakterin değişiminde gizlediği bilinmektedir. Var olan değişimin inandırıcılığı da iletinin amaca ulaşabilme derecesini arttırır. Yazar açık karakteri devingen karakter olarak yapılandırmıştır. Hayali yazar olmak olan bir kız çocuğunun, doğru yönlendirmeler ve emeği ile gerçekleştirdiği değişim yani öyküyü başarılı bir şekilde tamamlayabilmesi inandırıcıdır. Bu da yazarın devingen karakter yapılandırma başarısıdır. Okuyucunun, Fatoş’un değişiminini inandırıcı bulacağı için bu eserden kendine bir şeyler katabileceği düşünülmektedir.

\section{4. İleti (Mesaj)}

Eserdeki iletiler karakterlerin davranışları ve konuşmalarıyla verilmiştir. Eserdeki ana iletiyi şöyle özetleyebiliriz: İnsan, amacına ulaşabilmek için emek vermeli ve doğru yönlendirmelerden yararlanmalıdır. Eserdeki iletiler hedef kitleye uygundur. Onları olumlu davranışlara yöneltebilecek, açlk ve net iletiler sunulmuştur.

Eserdeki diğer bazı iletiler şunlardır: 
Features that children's books should have: A critical look at the works of Cemil Kavukçu named Bir Öykü Yazalım Mr? and Masal Anlatma Oyunu / İ. Aydın; M. Uzun (pp. 315-340)

"Okumayı sevdiğiniz için sizinle gurur duyuyorlar. Kim duymaz ki! ... Kitap okumanın ne kadar yararl bir şey olduğunu anlatmayacağım, onu zaten biliyorsunuz. (s. 25). Yazar karakteri ile kitap okumanın önemi iletisine yer veriliyor.

"Kitaplarla sıkı dost olmayan öykü yazabilir mi?” (s. 25). “Öyküye nasıl başlayacağım, ilk cümlem ne olacak gibi kaygllardan uzak duracağız." (s. 38). "Görmeye başlayacağız ve gördüklerimizi göstermek isteyeceğiz. Unutmayın ki öykü yazmak sözcüklerle resim yapmaktır.” (s. 38). Yazar öykücü kimliği ile eserde öykü yazabilmenin inceliklerini, eserdeki Yazar karakteri ağzından çocuklara iletiyor.

"Yazdıkça, yaşanmamış bir olayı yaşanmış gibi anlatmayı öğreneceğiz.” (s. 4o). Yazar oluşturulan eserlerin her zaman yaşanmış bir olayı anlatmadığı iletisini veriyor. Gerçeklik ve kurmaca gerçeklik kavramlarının farkını ortaya koyuyor.

"Bir öykü yazmak için yola çıktığımızda bakmak ile görmek arasındaki farkı anlayacağız." (s. 38). "Yazar, görmek ile bakmak arasındaki farkı ne güzel anlatmıştı. "Çoğu kez bakarız ama göremeyiz", demişti." (s. 69, 70). "Siz öyküyü kovalarsanız o kaçar. Bekleyin, geldiği zaman o kendini yazdıracaktır." (s. 77). "Anlatımın akıcı olması, okuyucuya öğretmek yerine söz edilen durumla ilgili ipuçları vermesi öyküyü değerli yapıyordu.” (s. 83). Yazar bakmak ve görmek kavramlarının farklı olduğu iletisini veriyor. Ayrıca öykü yazmanın nasıl olması gerektiği ile ilgili detaylara yeniden değiniyor.

"Anlatmak başka bir şeydi, bunları yazıya dökmek başka bir şey." (s. 7o). "Işste bu! Deyip ellerini çırpt Fatoş. Aslında Yazar'n söylediği tek bir şey var: Yazarken çok rahat ve özgür olmahyız." (s.78). Fatoş karakterinin ağzından, edinilen bilgiler ışığında yazmakla ilgili erişilen sonuçlar iletiliyor.

"Yazmak ne güzel bir şeydi." (s. 81.) Yazma eyleminin o yaş aralı̆̆ındaki çocuklar için bile eğlendirici, haz verici bir eylem olduğu iletisi yine başkahraman aracılı̆̆ıyla veriliyor.

"Bir kez daha gördüm ki kitap okumayı sevenlerin cümle kuruluşları, seçtikleri sözcükler, yazdıkları öyküler hemen fark ediliyor.” (s. 89). Kitap okuma eyleminin bireyler üzerindeki olumlu yönü iletisi verilmiştir.

“Okumak; yemek, içmek, uyumak gibi iç dünyamızın doğal bir gereksinimidir.” (s. 9o). Okuma eyleminin önemi iletisi verilmiştir.

\section{Dil ve anlatım}

Yazar akıcı, duru, açık, samimi bir anlatım yakalamıştır. Devrik cümleler sık sık kullanılmamış, cümleler arasına serpiştirilmiştir. Etken çatılı eylemler edilgen çatılı eylemlerden daha sık kullanılmıştır. Çocukların gündelik hayatta karşılaştığı kelimelerin tercih edilmesi de eserin anlaşlabilirliğini arttırmıştır. Bağlamdan hareketle anlamının tahmin edileceği sözcük ve sözcük grubu da bulunmaktadır. Bu da okurun kelime hazinesini geliştirecek bir durumdur. Ama eserde bilinmeyen kelimelerin yer aldığı bir sözlük bulunmamaktadır.

Eserde; gerekçeli söyleyişlere, farklı bakış açılarını veren anlatımlara yer verilmiştir. Bu durumun çocuğun zihinsel ve dil gelişimini olumlu etkileyeceği düşünülmektedir. Diyalogların anlatımda sıklıkla 
kullanılması eserdeki tekdüzeliği kırmıştır. Çocukların hoşuna gidebileceği düşünülen şarkı türü de eserde yer almaktadır. "Leylek leylek lepirdek. Hani bana çekirdek.” (s. 57).

Benzetme sanatı eserde sıklıkla kullanılmıştır. Örneğin: "Çünkü göl bir masal, güzel bir rüya gibidir.” "Masal gibi.” "Çünkü göl kadar büyük, incecik bir bulut gelip suyun üzerine yorgan gibi serilmişti."

Anlatımın deyim ve ikileme yönünden zengin olduğu göze çarpmaktadır. Eserdeki deyimlerin bazıları şunlardır: “dikkat kesilmek, içi burkulmak, gözünde büyümek, içi almamak, merakla beklemek, zorluklara göğüs germek, başını eğmek, hayal meyal hatırlamak acele etmek, hoşuna gitmek, canı istememek, kaşını çatmak, dudağını bükmek.”

Eserdeki bazı ikilemeler şunlardır: "çıtır çıtır, ballandıra ballandıra, zaman zaman, adım adım, yavaş yavaş, dalgin dalgin, pirll purıl, tane tane, sık sık, nazh nazh.”

Eserde yalnız birkaç yerde yazım ve noktalama hatası bulunmaktadır. Bunlar: "Avrupa Birliği’ne" (s. 42.) "Muhabbetkuşu" (s. 88). Bu küçük hatalar dışında yazım ve imla kurallarına uygun bir anlatım seçilmiştir.

Hedef kitlenin o yaş aralığında sıklıkla kullandığı telaffuzlar eserdeki karakterlerin konuşmalarında kullanılmıştır. Bu da eserin anlatımına doğallık ve samimiyet katmıştır. Örneğin; babiş, örtmenim.

Eserde hedef kitlenin kullanmakta zorlanacağı edat ve bağlaçlar kullanılmamıştır. Eserde beş duyu organına hitap eden bir anlatımla üslup canlı kılınmıştır.

\section{Plan (Kurgu)}

Kurgu çocukların anlayabileceği bir sırada ele alınmıştır. Serim, düğüm ve çözüm bölümleri kafa karışıklı̆̆ yaratmayacak, neden sonuç ilişkisi kurulabilecek ve sürükleyici bir şekilde planlanmıştır. Diğer ögelerinde yerli yerinde kullanıldığı bir plan kurulmuştur. Yazarın öykücülüğü burada eserin planını kuvvetlendirmiştir.

\section{Dış yapı özelliklerine yönelik bulgular}

\section{Boyut}

Eser 12,5x19,5 cm boyutlarındadır. Hedef kitlenin kolayca taşıyabileceği ve etkileşim kurabileceği boyutlardadır. Ayrıca yaş aralığı için hazırlanan kitaplarla da benzer boyutlardadır. Bu da kitaplık oluşturma alışkanlığını destekleyecek bir durumdur.

\section{Ciltleme}

Kitap tutkallama tekniği ile ciltlenmiştir. Sağlam bir ciltleme yapılmıştır. Bu durum kitabın uzun süre dağılmadan kullanılabilirliğine katkı sağlayacak, kitapla olan etkileşimi de olumlu etkileyecektir. 


\section{Kapak}
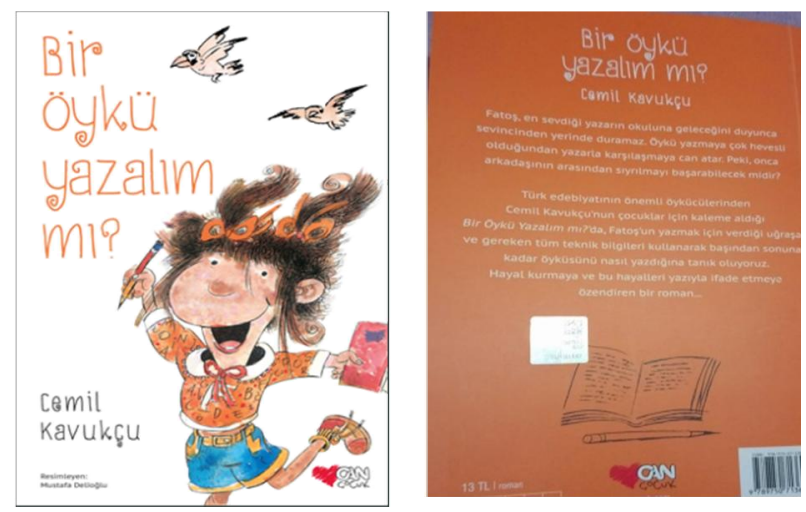

Şekil 2. İncelenen eserin ön ve arka kapak resmi (Kavukçu, 2020).

Kitap kapağında laklama işlemi uygulanmıştır. Kitabın sırt kısmında kitabın adı, yazarı ve yayınevi sembolü yerleştirilmiştir. Bu durum kitaba kolay ulaşmayı sağladığı gibi kütüphane oluşturma alışkanlığı kazanma sürecinde okura destek olacak niteliktedir. Kapak kolay yıpranmayacak bir hammaddeden hazırlanmıştır. Ön kapak resmi sanatçı duyarlılığı ile oluşturulmuştur. Olay örgüsü hakkında tahmin etme çalışmaları yaptırılabilecek niteliktedir. Başkahraman Fatoş olduğu düşünülen bir kız çocuğunun elinde kalem ve defterle çizildiği ön kapak resmi, olay örgüsünü sembolleştiren ögeleri içinde barındırmaktadır. Kız çocuğunun kıyafetinde harflerin bulunması ve biraz arkasında leyleklerin yer alması bu sembollere örnek verilebilir. Ayrıca kapaktaki resimlerde renklendirme yapılmıştır. Yalnız bu çizimler iki boyutludur. Kabartma, doku gibi üçüncü boyuttan yoksundur. Ön kapakta; yazar adı, resimleyen adı, yayınevi bilgisi, baskı sayısı gibi bilgilere yer verilmektedir. Arka kapak resminde kalem ve kitap çizimi yer almaktadır. Arka kapakta kitabı tanıtan, merak duygusunu güdüleyecek nitelikte bir tanıtım yazısı bulunmaktadır. Bunun dışında yazarı, okurlara tanıtan kısa bir yazı, kitabın hedef kitlesi, fiyatı bilgilerine de yer verilmiştir.

\section{Kâğıt cinsi}

İkinci hamur kâğıt kullanılmıştır. Sayfalar kolay açılmaktadır. Kâğıdın kalitesi yazıyı veya resimleri olumsuz etkilememektedir. Ayrıca yazı ve çizimlerin diğer sayfaya yansıma oranı düşüktür. Ama bu yansıma okumayı zorlaştırmamaktadır.

\section{Sayfa düzeni}

Sayfa düzeni 1,5 cm sol ve sağ, 1,9 cm alt ve üst boşluklarına göre planlanmıştır. Satır aralı̆̆ boşlukları da okuma eylemini zorlaştırmayacak bir biçimde kurgulanmıştır. Bu plan göz yormayan bir boşluk ve yazı dengesini sağlamıştır. Ayrıca boş olanlar okura not alabilme imkânı verecek genişliktedir. Sayfalar tek sütun olarak düzenlemiştir. Resim ve metin sayfaya uyumlu bir şekilde yerleştirilmiştir.

\section{Harfler}

Harfler okunabilir bir yazı stiliyle yazılmıştır. Harflerin büyüklüğü 12 puntodur. Hedef kitlenin; Türk abecesindeki harfleri tanımasına, sözcükleri kolayca okumasına olanak sağlayacak ve gözünü yormayacak boyutlardadır. 


\section{Resimleme}

Kitabın resimlemeleri Mustafa Delioğlu'na aittir. Sanatçı duyarlılı̆̆ı ile olayları, durumları, karakterleri konu edilen çizimler kullanılmıştır. Resimler sadece çizgiseldir. Doku gibi bir üçüncü boyut katılmamıştır. Kapak resimlemesi hariç resimlerde renklendirme kullanılmamıştır. Çizerin üslubunun özgünlüğü ve hedef kitlenin yaş aralığı düşünülürse bu kabul edilebilir bir durumdur. Gerçeğin kurgulanarak yansıtılması da sanatsal eserlerde olmazsa olmazdır. Çizgiler, gerçeği fotoğraf gerçekliğinden ziyade kurmaca bir gerçeklik ile yansıtmıştır. Resimler sözlü metni tamamlayacak bir niteliktedir. Sözcüklerle anlatılmayanlar çizim gücüyle çocuklara yansıtılmaktadır. Resimler, olay örgüsünden kesitler sunmakta, kahramanları ve mekânları betimleyerek eserin çocuğun belleğinde canlanmasına yardımcı olmaktadır.

Resimler, çocuğu tek başına; düşündürecek, eğlendirebilecek, resim yapma isteği uyandırabilecek kadar dikkat çekici değildir. Ama bilinçli bir yönlendirme ile bu hale gelebilir. Eserde 17 resim bulunmaktadır. Eserdeki yazı ve resim oranı hedef kitleye uygundur. Eserden birkaç resim örneği aşağıda sunulmuştur.
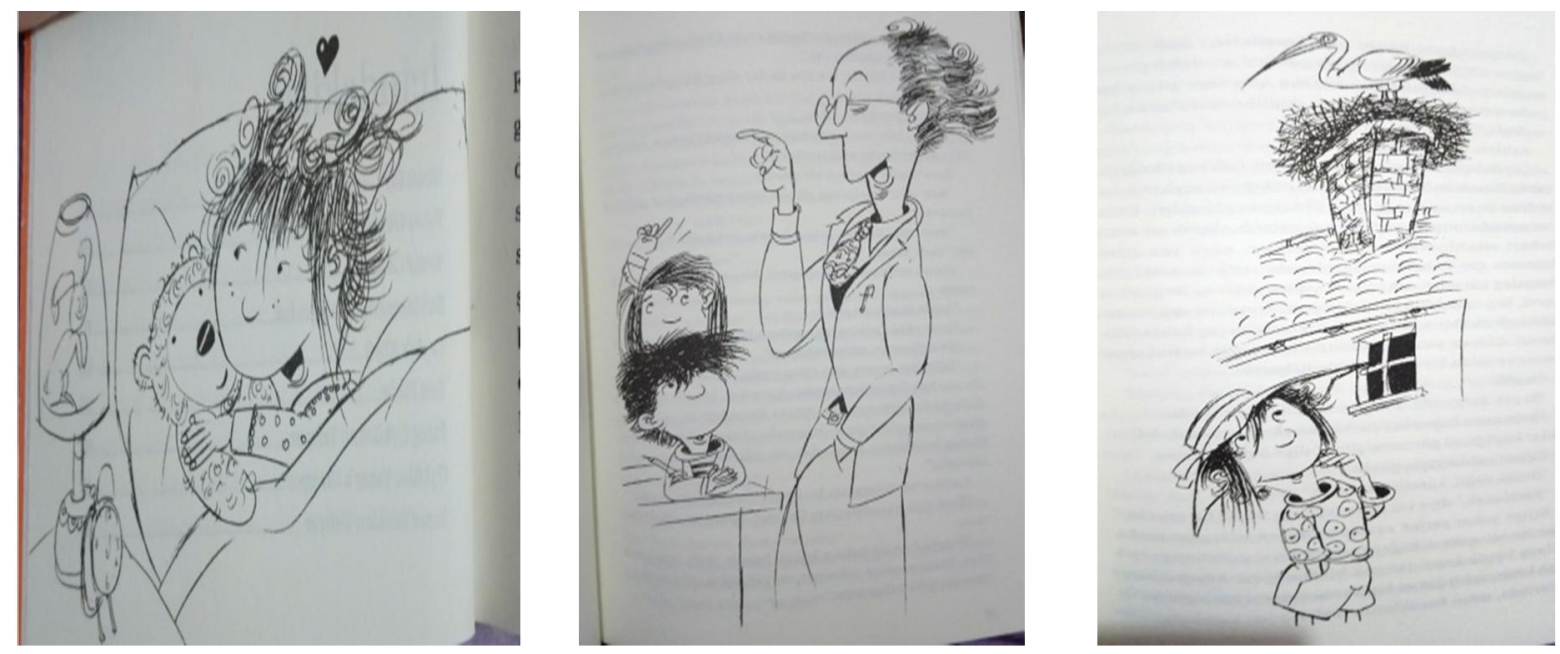

Şekil 3. İncelenen eserden resim örnekleri (Kavukçu, 2020: 8, 33, 51).

\section{Masal kurma oyunu adlı esere yönelik bulgular}

Kitabın Adı: Masal Kurma Oyunu

Kitabın Yazarı: Cemil Kavukçu

Resimleyen: Mustafa Delioğlu

Yaş: $8,9,10+$ 


\section{İç yapı özelliklerine yönelik bulgular}

\section{Konu}

Eserde; Bora adında bir çocuğun Ayvalık'ta teyzesinin yanında kuzeni ve eniştesi ile beraber geçirdiği eğlenceli günlerden birinde oynadıkları masal anlatma oyunu konu edilmektedir. Gerçekçi ve hedef kitleye uygun bir konu seçilmiştir. Hedef kitlenin yaşadığı veya yaşaması muhtemel olaylar eserde slklıkla işlenmiştir. Konu okuru masal dinleme ve anlatma etkinliklerine teşvik edebilecek ve bu etkinliklere olumlu tutum kazandırabilecek niteliktedir. Eserin olay örgüsü hedef kitlenin merak duygusunu nerdeyse her aşamada canlı tutacak niteliktedir.

Olay örgüsü 14 kesitte özetlenebilir:

1. Bora, Ayvalık'ta teyzesinin yanında yaz tatilini geçirmektedir. Denizde sık slk yüzüyor ve oranın doğa güzelliklerinin tadını çıkarıyormuş. Hatta Bora uzakta olan bir adaya Dozi adını koymuş ve onu konu alan masallar anlatıyormuş. Bunu duyan kuzeni Ayça'da bu durumu gülünç bulup onunla dalga geçiyormuş.

2. Bir akşam mangal sonrası, ortaklaşa bir sofra bahçeye kurulmuş. Keyifle sofrada otururken birden elektrikler kesilmiş. Sofranın başında, yıldızların ışı̆̆ı altında ve doğanın sesinin eşliği ile öylece kalakalmışlar.

3. Eniştesinin aklına birden bir fikir gelmiş. Hadi herkes bir masal anlatsın demiş. Bora önce masal bilmediğini söylemiş. Ama eniştesi, masal dinleyen kendi anlatabileceği bir masalı içinde büyütür demiş. Yaşlı oduncu masalını anlatmaya başlamış. Masal "Uzun Ağaçlar" adında bir ülkede geçiyormuş. Yaşlı oduncunun Şipka adında bir keçisi ve bir de Mahmur adında köpeği varmış.

4. Bir gün yaşlı oduncunun kulübesinden nedeni anlaşılmayan tuhaf bir ışık gelmiş. Bu ışı̆̆ın sebebi, adamın bir akşam vakti bulduğu bir tavus kuşuymuş. Enişte masala devam ederken birden elektrikler gelmiş. Ama herkesin aklı masaldaymış. Masala kalındığı yerden devam edilmiş.

5. Yaşlı oduncu bir sabah uyandığında tavus kuşu ve Şipka'nın olmadığını fark etmiş. Bu duruma anlam verememiş. Enişte tam bu sırada: "E karpuz yemeyecek miyiz?" diye sormuş. Ama herkesin aklı yine masaldaymış. Masalın merakı ile alelacele sofraya bir şeyler koyulmuş.

6. Bu oyunun adının masal kurma olduğu tekrar söylenmiş. Bu oyunda masal ortaklaşa kuruluyormuş. İşte bu nedenle masalın devamını Bora'nın teyzesi getirmiş. Aynur teyze anlatacağı masalın adının "Gulin" olduğunu söylemiş. Bu masal, ilk masalla aynı ülkede ama bu ülkenin gizli bir bölgesinde geçiyormuş. Adı da Kuşlar Sarayı imiş. Bu sarayı Zuhra adında albatros kuşu bir kraliçe yönetiyormuş. Bu ülkede Minik Kanatlar Bayramı adı verilen bir bayramda yavru kuşlar sergileniyormuş.

7. Bayrama bu yıl farklı bir kuş katılmış. Guli'nin yavrusu Gulin imiş. Bu tavus kuşu diğerlerinden farklıymış etrafa ışık saçıyormuş. Herkes böyle bir şeyi ilk defa görmüş. Bora hemen bu yaşlı oduncunun tavus kuşu değil mi, diye sormuş? Ama teyzesi masalın akışını bozmamak için sessiz kalmış.

8. Guli yavrusunu daha ilk doğduğunda Zuhra'ya göstermiş. Zuhra bilginlere danışmış ve bu yavrunun tahtın yeni varisi olduğunu anlamış. Ama bir an kızı Anişa aklına gelmiş tedirgin olmuş. Anişa taht için 
yeterli değilmiş. Bu nedenle kraliçe bu durumun bayrama kadar saklanmasını istemiş. Anişa bayram günü bu durumun bir uğursuzluk olduğunu söylemiş. Bu durum karşısında tavus kuşlarının ceza almasını istemiş ama kimse onu ciddiye almamış

9. Anişa tahta geçebilmek için tavus kuşundan kurtulmak istemiş. Ama ona kimse yardım etmediği için cezalı ve sürgünde olan Puro adlı bir kuştan yardım istemiş. Puro Gulin'den kurtulması karşllı̆̆nda Anişa'ya casusluk teklif etmiş. Puro bir tuzak kurmuş ve büyülü bir badem tozu hazırlamış. Yalnız işleri ters gitmiş ve tuzağa Guli düşmüş. Birden bir keçiye dönüşmüş. Bu sırada Bora hemen araya girmiş. Bu oduncunun kulübesindeki keçi değil mi demiş? Teyzesi de evet Bora çok dikkatlisin demiş.

10. Hem bir şeyler yemiş hem de masalı dinlemeye devam etmişler. Gulin o keçinin annesi olduğunu anlamış. Ama Kuşlar Sarayı'ndaki kimseyi bu duruma inandıramamış. Keçi olan Guli ormanda bir kulübeye gitmiş. Bora hemen bu kulübe de yaşlı oduncunun kulübesi değil mi, demiş? Sonra bu kulübenin o kulübe olduğu anlaşılmış. Masalın bundan sonrasını oyunun kurallarına uygun olması için devamını Ayça anlatmış.

11. Ayça'nın masalının adı "Gulin Annesini Arıyor". Bora sen bu masalı biliyordun diye önce kızmış. Ama Ayça tabi ki bilmiyorum. Oyunun kuralı herkesin masalı dinlerken içinde büyüyen masalı anlatması demiş. Ben de kurala uyuyorum demiş. Masalı anlatmaya devam etmiş. Bora'da oduncuya ne olduğunu sormuş. Ayça'da bilmem belki onu da sen anlatırsın demiş ve masalına devam etmiş.

12. Kuşlar Sarayı biraz hareketliymiş. Keçinin ülkeye girebilmesi panik yaratmış. Gulin ile konuşan kraliçe bu durumda bir büyü olduğunu anlamışlar. Olayların çözüldüğünü anlayan Anişa panikle Puro'nun yanına gitmiş. Bora işler iyice karıştı desene demiş. Ayça da aksine çözülüyor demiş. Sadece sırayla anlatmadığım için karışık gelmiştir demiş.

13. Zuhra durumun Anişa ile bağlantısını çözer gibi olmuşlar. Ayça masalın devamını Bora’nın getirmesini istemiş. Bora önce ne anlatacağını bilememiş. Ama sonradan yaşlı oduncunun sabah uyanıp keçi ve tavus kuşu bulamadığı sabahtan devam etmiş. Tavus kuşunun annesi keçi Guli'yi bulup onu tekrar kuşa dönüştürüp evlerine döndüğünü anlatmış.

14. Masalın saklı kalan diğer kısımlarını, Anişa’nın suçunu itiraf etmesini, olayların çözülmesini de Bora'nın teyzesi ve en sonda eniştesi anlatıyor. Her masal gibi iyilerin ödüllendirildiği ve kötülerin cezalandırıldığı bir masal oluyor. Bora biten bu masalla bu oyunu ne kadar çok sevdiğini fark ediyor. Evlerine ilk gittiği zaman bu oyunu oynayacağını hatta masalın konusunun bile hayal kahramanı Dozi olacağını söylüyor. Ama dayanamayıp sabah oynayalım diyor. Herkes birbirine iyi geceler diyor ve uyumaya gidiyorlar.

Eserde Bora ve Ayça'nın ve masal kahramanlarının da taht için yaşadığı çatışmaları kişi kişi çatışması içerisinde ele alınabilir. Çatışmalar merak duygusunu canlı tutmuştur. Konu dinamizm unsurlarını başarılı bir şekilde barındırmaktadır. Konunun yapılandırmasını zayıflatan ögelerden; rastlantısallık, abartılmış merak, duygusallık unsurlarından hiçbirine yer verilmemiştir.

\section{Tema (İzlek)}

Eserde hayal gücünün önemi, doğa sevgisi, aile içi iletişim, kıskançlığın kötülüğü gibi masal temaları işlenmiştir. Çocuklar için uygun olarak değerlendirilen bu temalar birbiri içinde uyumlu bir biçimde 
sunulmuştur. Temalar çocukları olumlu davranışlara yöneltecek, bilişsel ve duyuşsal yönden besleyecek türdendir. Konu ve tema arasında sağlam ve birbirini tamamlayan bir bağ kurulmuştur. Yazar eserin temasında politik veya ideolojik bir güdümlülük sergilememiştir.

\section{Karakterler}

Eserde kitabın seslendiği yaş aralığı ile benzer iki karakter bulunmaktadır. Bunlar Ayça ve Bora'dır. Seçilen bu karakterler yaşlarının gelişim dönemi özelliklerini sergilemektedir. Örneğin: Bora, adaya Dozi adını verip olağanüstülüklerle dolu kısa hikâyeler anlatmaktadır. Güneş’in her zamanki batışının Bora'nın dünyasına yansıyışı, çocuksu bir bakışla betimlenir. Ayrıca bu hikâyelerde o yaş aralığındaki çocuk dilinin şairaneliği örneklendirilir. Bora'nın cansız varlıkları konuşturması ama bunun oyun olduğunun farkında olması ve kendi yaşıtı kuzeni ile küçük kavgalar etmesi de bu yaş çocuklarda sık görülen bir durumdur. Bu detayların karakterlere sindirilmiş olması, yazarın inandırıcı bir karakter geliştirdiğini göstermektedir. Ayrıca okuyucunun kitap karakterleri ile inandırıcı bulduğu ölçüde özdeşim kurduğu düşünülürse, eser bu açıdan başarılıdır denebilir.

Eserde bir açık karakter geliştirilmiştir. Bu da Bora'dır. Çocuk eserlerinde kafa karışıklığı yaratmamak için tek açık karakter tercih edilmesi detayına uyulmuştur. Karakter davranış ve konuşmalar yoluyla geliştirilmiştir. Çocukların açık karakteri tanıması gerektiği kadar bilgi verilmiştir. Gereksiz detaylara girilmemiştir.

Eserde kapalı karakter kadrosu geniştir. Bunlar Bora'nın kuzeni Ayça, teyzesi Aynur, eniştesi Nedim'dir. Bunlara ek olarak masalda adı geçen Guli, Gulin, Zuhra, Anişa, Puro karakterleri de eklenebilir. Kapalı karakterler de olması gerektiği gibi okuyucuya fazla tanıtılmadan oluşturulmuştur.

Eserde devingen karakter de yine açık karakter olan Bora'dır. Hikâyenin başında masal anlatamayan karakter süreç sonunda bu etkinliği yapabilir hale gelmiştir. Yazar Bora'nın yaşadığı değişim üzerinden iletiler vermiştir. Bu değişim inandırııı bir şekilde kurgulanmıştır. Okuyucunun, bu değişimi inandırıcı bulacağı için eserden kendine bir şeyler katabileceği düşünülmektedir.

\section{4. İleti (Mesaj)}

Ana düşünce; insanların hayal gücünün yardımı ile güzel vakit geçirip mutlu olabilecekleri iletisi üzerine kurulurdur. Eserde iletilerin açı, net ve çocukların gelişim seviyelerine uygun olduğu gözlenmiştir. İletiler genelde kahramanların konuşmaları aracılı̆̆ıyla aktarılmıştır. Okuru olumlu davranışlara yöneltecek iletiler yer almaktadır.

Eserdeki diğer bazı iletiler şunlardır;

“Ona yardım ettiği için çok mutluydu.” (s. 12). Başka insanlara yardım etmek mutluluk verir.

"Masal dediğin öyle bir şeydir ki, ben anlatmaya başlayınca sen beni dinlerken kendi masalın da büyümeye başlayacak.” (s. 22). Masal anlatma masal dinlenerek öğrenilir iletisi.

"Annelerle çocukların sözcükleri kullanmadan sadece gözleriyle anlaştı̆̆ o sihirli dili bulmuşlardır belki de.” (s. 48). Anne ve çocukları arasında güçlü ve özel bir bağ vardır. Bu bağ bazen konuşmadan da anlaşabilmeyi sağlar iletisi. 
"Benim kızım da iyi masalcıymış, dedi Nedim enişte gururla. Dinleyeni merakta bırakmayı biliyor." (s.64). İyi bir masal anlatıcısı olmak insanları meraklandırabilmeyi de gerektirir iletisi.

“Acele edersek bir sonuca ulaşamayız.” (s. 82). Acele etmek bazen amacımıza ulaşmayı engeller iletisi.

"Yine de önemli olan hatayı yapmak değil onu bir daha tekrarlamamaktır." (s. 89). İnsanlar yaptıkları hatalardan ders çıkarmalı ve bunları tekrarlamamak için çabalamalıdır.

\section{Dil ve anlatım}

Yazar akıcı, duru, açık bir anlatım tercih etmiştir. Devrik cümleler sık sık kullanılmamış, cümleler arasına serpiştirilmiş. Etken çatılı eylemler eserde edilgen çatılı eylemlere göre daha çok tercih edilmiştir. Çocukların gündelik hayatta karşılaştığı kelimelerin tercih edilmesi de eserin anlaşlabilirliğini arttırmıştır. Bağlamdan hareketle anlamının tahmin edileceği sözcük ve sözcük grubu da bulunmaktadır. Bu da çocuğun kelime hazinesini geliştirecek bir durumdur. Ama eserde bilinmeyen kelimelerin yer aldığı bir sözlük bulunmamaktadır.

Eserde; gerekçeli söyleyişlere, farklı bakış açılarını veren anlatımlara yer verilmiştir. Bu ifadelerin çocuğun zihinsel ve dil gelişimini olumlu etkileyeceği düşünülmektedir. Sıklıkla kullanılan diyaloglar eserin anlatımındaki tekdüzeliği kırmıştır. Çocukların hoşuna gidebileceği düşünülen şarkı türü de eserde yer almaktadır. "Dozi, Dozi tembel Dozi. Uyuyan halkın bekler seni." (s. 9).

Eserin türü roman ama kurgunun içerisinde bir masal bulunduğu için eserde masal türünün anlatım özelliklerine rastlanılmaktadır. Benzetme sanatı eserde sıklıkla kullanılmıştır. Örneğin: mobese kamerası gibi, yılbaşı ağacı gibi, şurup gibi.

Anlatımın; deyim ve ikileme yönünden zengin olduğu göze çarpmaktadır. Eserdeki deyimlerin bazıları: hâl hatır sorma, gözü pek olmak, hapı yutma, canı sıkılmak, elinden geleni yapma, dört dönmek, gözünü açmak. Eserdeki bazı ikilemeler: katıla katıla, ağır ağır, kıkır kıkır, çıtır çıtır, usul usul, yavaş yavaş, ışıl ışıl, zıp zıp, tembel tembel, boş boş, boncuk boncuk, uzun uzun, pırıl pırıl.

Eserde yazım ve noktalama yanlışı bulunmamaktadır. Hedef kitlenin o yaş aralığında sıklıkla kullandığı telaffuzlar eserdeki karakterlerin konuşmalarında kullanılmıştır. Bu da eserin anlatımına doğallık ve samimiyet katmıştır. Örneğin; akıllım.

Eserde hedef kitlenin kullanmakta zorlanacağı edat ve bağlaçlar kullanılmamıştır. Eserde beş duyu organına hitap eden bir anlatımla üslup canlı kllınmıştır.

\section{Plan (Kurgu)}

Roman kurgusunun içerisine kahramanların anlatışı ile şekillenen bir masal kurgusu yerleştirilmiştir. Kahramanların her birinin masalın bir başka yönünü anlatması ile okura masalın bütünü sunulmaktadır. İç içe ama okurun anlamasına uygun, merak duygusunu her aşamada sunan başarılı bir kurgu oluşturulmuştur. Serim, düğüm, çözüm bölümleri okurun anlamasını kolaylaştıracak bir düzende sunulmuştur. 
Features that children's books should have: A critical look at the works of Cemil Kavukçu named Bir Öykü Yazalım Mr? and Masal Anlatma Oyunu / İ. Aydın; M. Uzun (pp. 315-340)

\section{Dış yapı özelliklerine yönelik bulgular}

\section{Boyut}

Eser 12,5x19,5 cm boyutlarındadır. Hedef kitlenin kolayca taşıyabileceği ve etkileşim kurabileceği boyutlardadır. Ayrıca yaş aralığı için hazırlanan kitaplarla da benzer boyutlardadır. Bu da kitaplık oluşturma alışkanlığını destekleyecek bir durumdur.

\section{Ciltleme}

Kitap tutkallama tekniği ile ciltlenmiştir. Sağlam bir ciltleme yapılmıştır. Bu durum da kitabın uzun süre dağılmadan kullanılabilirliğini sağlar. Kitapla olan etkileşimi de olumlu etkiler.

\section{Kapak}
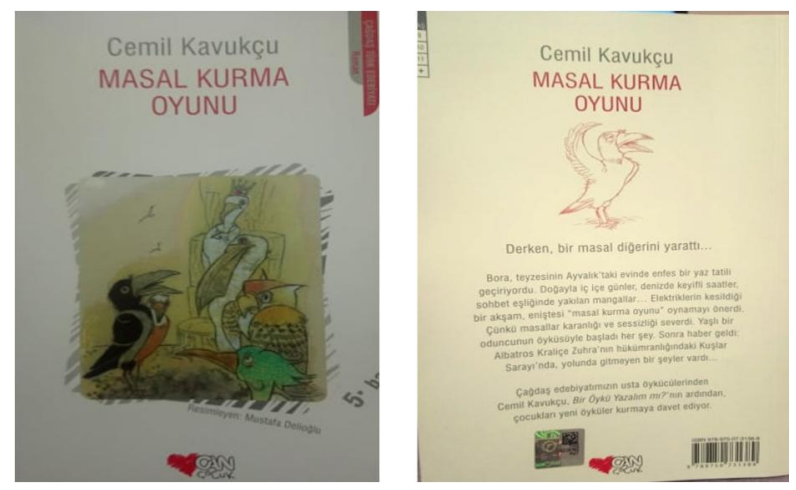

Şekil 4. İncelenen eserin en ve arka kapak resmi (Kavukçu, 2019).

Kitap kapağında laklama işlemi uygulanmıştır. Kitabın sırt kısmında kitabın adı, yazarı ve yayınevi sembolü yerleştirilmiştir. Bu durum kitaba kolay ulaşmayı sağladığı gibi kütüphane oluşturma alışkanlığı kazanma sürecinde okura destek olacak niteliktedir. Kapak kolay yıpranmayacak bir hammaddeden hazırlanmıştır. Bu kitapla etkileşimi olumlu etkileyen bir olgudur. Ön kapak resmi olay örgüsündeki masaldan bir kesitin resmedildiği renkli bir çizimdir. Yönlendirmelerle ve eserin adından hareketle konu hakkında tahmin çalışmaları yaptırılabilir niteliktedir. Kapakta doku, kabartma gibi üçüncü bir boyut bulunmamaktadır. Bu tür detayların eksikliği kapağın çekiciliğini azaltmaktadır. Ön kapakta ayrıca yazarın, çizerin, yayınevinin adı, eserin türü ve basım sayısı bilgileri bulunmaktadır. Arka kapak resminde dikkat çekici olmayan çizgisel bir resim bulunmaktadır. Arka kapak yazısı konuyu çocuklara fisıldayan, kitabı okumaya davet eden bir üslupla kaleme alınmıştır. Ayrıca arka kapakta kitabın hedef kitlesinin yaş aralığı da belirtilmiştir.

\section{Kâğıt cinsi}

İkinci hamur kâğıt kullanılmıştır. Sayfalar kolay açılmaktadır. Kâğıdın kalitesi yazıyı veya resimleri olumsuz etkilememektedir. Ayrıca yazı ve çizimlerin diğer sayfaya yansıma oranı düşüktür. Ama bu yansıma okumayı zorlaştırmamaktadır. Bu detaylar okurun kitapla etkileşimini olumlu etkilemektedir. 


\section{Sayfa düzeni}

Sayfa düzeni çocukların okuma eylemini zorlaştırmayacak şekilde planlamıştır. Sayfalar tek sütun olarak düzenlemiştir. Sayfa boşlukları çocukların notlar alabileceği genişliktedir. Sayfa düzeni $1,5 \mathrm{~cm}$ sol ve sağ, $1,9 \mathrm{~cm}$ alt ve üst boşluklarına göre planlanmıştır. Satır aralığı boşlukları da okumayı kolaylaştıracak bir biçimde planlanmıştır. Resim ve metin sayfaya uyumlu bir şekilde yerleştirilmiştir.

\section{Harfler}

Harfler okunabilir bir yazı stiliyle yazılmıştır. Harflerin büyüklüğü 12 puntodur. Hedef kitlenin, Türk abecesindeki harfleri tanımasına, sözcükleri kolayca okumasına olanak sağlayacak ve gözünü yormayacak boyutlardadır

\section{Resimler}

Kitabın resimleri Mustafa Delioğlu'na aittir. Sanatçı duyarlılığı ile olayları, durumları, karakterleri konu edilen çizimler kullanılmıştır. Resimler sadece çizgiseldir. Doku gibi bir üçüncü boyut yoktur. Kapak resimlemesi hariç, resimlerde renklendirme kullanılmamıştır. Çizimlerin niteliği ve hedef kitlenin yaş aralığı göz önünde bulundurulursa renk kullanılmaması göz ardı edilebilir. Çizgiler, gerçeği fotoğraf gerçekliğinden ziyade kurmaca bir gerçeklik ile yansıtmıştır. Çizerin üslubu özgündür. Resimler sözlü metni tamamlayacak bir niteliktedir. Sözcüklerle anlatılmayanlar çizim gücüyle çocuklara yansıtılmaktadır. Resimler, olay örgüsünden kesitler sunmaktadır. Kahramanları ve mekânları da çizimlerle betimleyerek eserin çocuğun belleğinde canlanmasına yardımcı olmaktadır. Resimler, çocuğu tek başına; düşündürecek, eğlendirebilecek, resim yapma isteği uyandırabilecek kadar dikkat çekici değildir. Ama bilinçli bir yönlendirme ile bu duruma gelebilir.

Eserde 17 resim bulunmaktadır. Eserdeki yazı ve resim oranı hedef kitleye uygundur. Eserdeki resimlerden birkaçı aşağıda sunulmuştur.
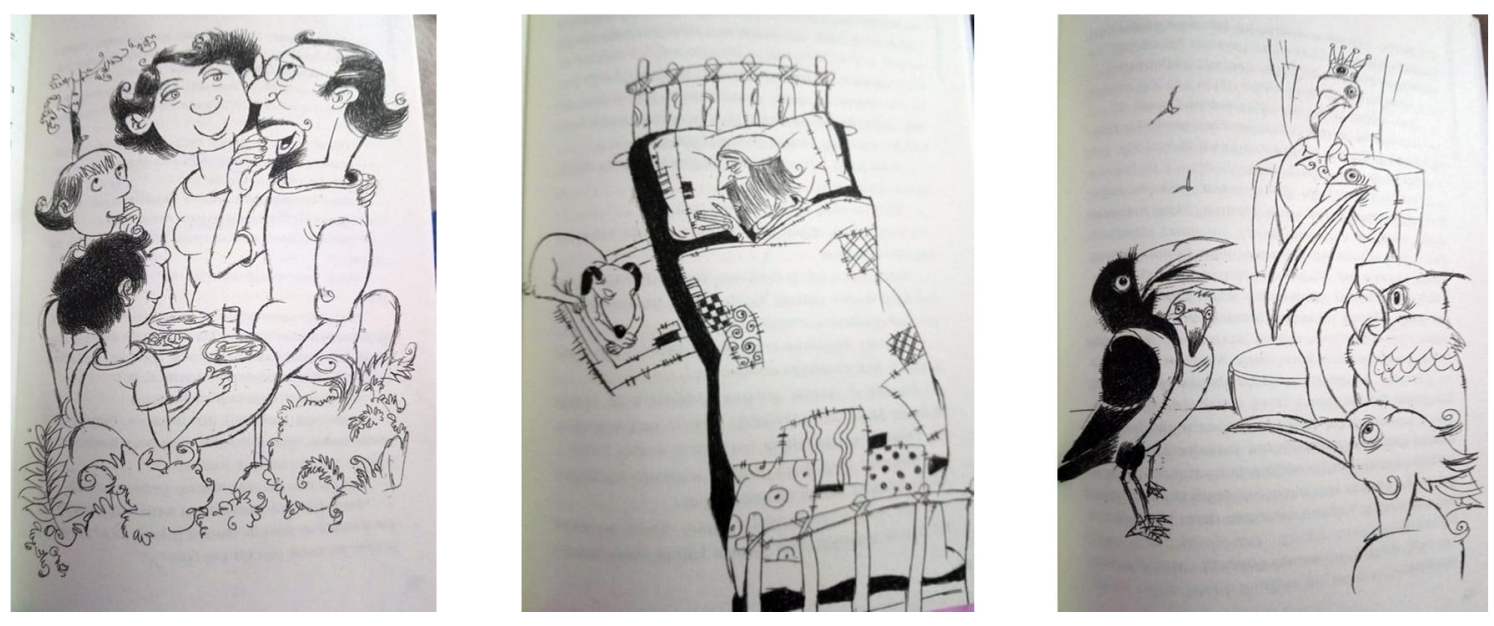

Şekil 5. İncelenen eserden resim örnekleri (Kavukçu, 2019: 21, 73, 59). 


\section{Sonuç ve tartışma}

Alan yazınında Cemil Kavukçu'nun yetişkinler için yazdığı öyküler hakkında 6 teze rastlanmaktadır. Çocuklar için yazdığı eserler hakkında tez çalışması bulunmamaktadır. Cemil Kavukçu'nun çocuklar için yazdığı eserler hakkında yalnızca iki çalışma bulunmaktadır. Bunlardan biri Barutçu ve Açık'ın (2018) Masal Anlatma Oyunu ve Bir Öykü Yazalım mı? eserlerinin de incelendiği, "Çocuk Edebiyatı Ürünlerinde Yer Alan Deyimlerin Kültür Aktarımındaki Rolü ve Türkçe Ders Kitaplarındaki Deyimlerle Örtüşme Düzeyi” adlı çalışmasıdır. Çalışmada Barutçu ve Açık (2018) Cemil Kavukçu'nun eserlerinde bulunan deyimlerin, önemli deyimler sözlüklerinde var olan deyimler olduğunu tespit etmiştir. Eserdeki deyimlerin Türkçe ders kitaplarındaki deyimlerle örtüşme düzeyinin de oldukça yüksek olduğu ifade edilmiştir. Halk kültürünün aktarımında önemli işlevler üstlenen deyimlerin niceliği ise eserlerde yeterli bulunmuştur. Ayrıca eserlerin, çocukların ruh sağlı̆̆ına uygun özellikler barındırdı̆̆ 1 da belirtilmiştir. Diğer çalışma ise Özçelebi'nin (2011) "Cemil Kavukçu'nun Çocuk Kitaplarına Eleştirel Bir Bakış” adlı çalışmasıdır. Özçelebi (2011) bu çalışmasında; Kavukçu'nun, eserlerini çocuk edebiyatının ilkelerinden ödün vermeden, çocuklar sizin için yazıyorum demeden, edebiyatın kendi sınırları içerisinde kaleme aldığına; eserlerinde çocuklara uygun bir dil kullanarak sıradan yaşamları sıra dışı bir üslupla anlattığına, eserlerin çocukları gerçeklikle birlikte düşsel/kurgusal bir yolculuğa çıkarmak için birebir olduğuna vurgu yapmıştır. İki çalışmada da Kavukçu'nun eserleri, çocuk kitaplarının taşıması gereken özellikler bağlamında kapsamlı bir şekilde incelenmemiştir. Bu çalışmayı diğerlerinden ayıran nokta burasıdır. Araştırmada bulgulardan hareketle şu sonuçlara ulaşılmıştır:

\section{Eserler iç yapı özelliklerine uygun tasarlanmıştır.}

Çocukların ilgisini çekebilecek, hedef kitlenin güncel hayatı ile benzerlikler taşıyan gerçekçi bir konu seçimi yapılmıştır. Eserler konu yönünden hedef kitlenin gelişim özelliklerine uygundur. Eserlerdeki gerçeklik içerisine çocuğun düş gücünü besleyecek ögeler de başarılı bir şekilde yerleştirilmiştir. Konular çocukların anlama ve anlatma becerilerini geliştirebilecek; masal dinleme ve anlatma, öykü yazma gibi farklı etkinliklere teşvik edebilecek türdendir. Oğuzkan'a (2013, s. 371) göre çocuk eserlerinde konu dinamizm barındırmalıdır. Eserlerin konusunu yapılandıran olay örgüsü ve çatışma dinamizm unsurlarını içinde başarılı bir şekilde barındırmaktadır. İyi yapılandırılmış bir konuyu bozabilecek unsurlardan hiçbirine yer verilmemiş olduğu da görülmektedir. Çatışma ve olay örgüsü çocukların gelişim seviyesine uygundur. Eser, okuyucuya tüm bu ögeleri ile sürükleyici bir okuma serüveni sağlayacaktır.

Çocuk edebiyatının temel işlevlerinden biri de okuma, yazma alışkanlığı kazanan ve kendini ifade edebilen bireyler yetiştirmektir. Eserlerin teması bu işlevi destekleyecek yönde seçilmiştir. Eserlerde konu ve tema arasında birbirini destekleyen güçlü bir ilişki de bulunmaktadır. Yazar eserde çocukların özdeşim kurabileceği inandırıcı karakterler geliştirmiştir. Okuyucu hedef kitlesinin gelişim özelliklerinin karakter içerisine yedirilmiş olması bunun en önemli nedenlerinden biri olarak görülmektedir. Eserdeki karakterlerin cansız varlıkları konuşturarak oyun oynaması ve bunun oyun olduklarının farkında olması, karakterlerin yetişkinlere büyüdüklerini ispat etme çabaları, yer yer yaşıtları ile yaşadığı küçük çatışmalar bunlara örnektir. Sever'e (2019b, s. 115) göre eserde küçük okurun karaktere ilgi göstermesini sağlayan en önemli unsurlardan biri onun yaşadığı değişimdir. Eserlerdeki devingen karakterlerin yaşadı $\breve{g}$ değişim bir süreç içerisinde, kendi çabaları ve çevrenin olumlu desteği ile inandırıcı bir şekilde gerçekleşmiştir. Okuyucun inandırıcı bulacağı bu olumlu yöndeki değişimler çocuklara katkı sağlayabilecek niteliktedir. Masal anlatmanın inceliklerini öğrenen 
Bora ve öykü yazmanın süreçlerini öğrenen Fatoş karakteri buna örnektir. Ayrıca Cemil Kavukçu, ilk incelenen eserindeki Yazar karakteri ile okuru kurmaca bir gerçeklikle de olsa bir öykü yazarı ile tanıştırma başarısını göstermektedir. İyi yapılandırılan Yazar karakteri; yazar olmanın, öykü yazmanın aşamalarını küçük okura bir kurgu içerisinde sunmaktadır.

Eserlerde çocuklara kazandırılmak istenenler, ders kitaplarındaki gibi bir öğreticilikle değil edebi eserin kendi kurgusu içerisinde ele alınmaktadır. İletiler çocukları besleyecek nitelikte ve açık ve net ifade edilmiştir. Eserde, çocukları okuma, yazma, dinleme, konuşma etkinliklerine olumlu tutum kazandırabilecek ve bu etkinliklere yönlendirebilecek iletiler başarılı bir şekilde işlenmiştir. Eserlerin dil ve anlatımı duru, açık ve akıcıdır. Çocukların gündelik hayatında sıklıkla karşılaştığı kelimeler tercih edilmiştir. Bağlamdan hareketle tahmin edilebilecek kelime ve kelime grupları da vardır. Anlatımda diyalogların ve farklı türden bir şarkıya yer verilmesi anlatımdaki tekdüzeliği kırmıştır. Deyim, ikileme yönünden zengin bir anlatım tercih edilmiştir. Eserlerde bir sözlük kullanılmamıştır. Eserlerin planı ustaca kurgulanmıştır. İlk incelenen eserdeki kurguda, bir hikâyenin içerisine bir hikâye yazma süreci eklendiği ve bunu çocukların anlayabileceği bir planda gerçekleştirildiği görülmektedir. İkinci eserde de kurguda, akraba sohbeti içerisine diyaloglarla şekillenen bir masal kurgusu açı ve anlaşılır bir şekilde yerleştirildiği görülmektedir. Bunlar yazarın kurgudaki başarısını destekleyen etmenler olarak değerlendirilmiştir.

\section{Eserler dış yapı özelliklerine uygun tasarlanmıştır.}

Eserlerde hedef kitle için uygun bir boyut, ciltleme, sayfa düzeni, kâ̆ğtt cinsi ve harfler seçildiği gözlenmiştir. Kapaklar kaliteli bir hammaddeden ve cezbedici resimlerle hazırlanmıştır. Kitabın resimleri çizer Mustafa Delioğlu'nun özgün üslubuyla renksiz tasarlanmıştır. Renkli olmayışının dezavantajını, çizerin özgün üslubunun azalttı̆̆ı öngörülmüştür.

Çalışmada ulaşılan sonuçlardan hareketle şu önerilerde bulunulabilir:

Eserlere okurun söz dağarcığını geliştirmede etkili olabileceği düşünülen bir sözlükçe eklenebilir.

Eserlerin, çocuk kitaplarının taşıması gereken özelliklere uygunluğundan dolayı yazarın öykü metinlerine Türkçe ders kitaplarında yer verilebilir.

\section{Kaynakça}

Akal, A. (2008). Eğitim-Sen Çocuk ve gençlik edebiyatı ölçütleri için eleştiri ve öneriler. http://www.egitimsen.org.tr/down/cocuk_edebiyati_olcutleri.pdf.

Barutçu, T., Açlk, F. (2018). Çocuk edebiyatı ürünlerinde yer alan deyimlerin kültür aktarımındaki rolü ve Türkçe ders kitaplarındaki deyimlerle örtüşme düzeyi. Bilig-Türk Dünyası Sosyal Bilimler Dergisi, 86, 183-209.

Chelebourg, C. ve Marcoin, F. (2007). La Littérature de jeunesse. Paris: Armand Colin.

Çer, E. (2016a). Çocuk Edebiyatı. o-6 Yaş çocuk kitaplarında çocuk gerçekliği ve çocuğa görelik. Ankara: Eğiten Kitap.

Çer, E. (2016b). Türkçe öğretiminde çocuğa görelik ilkesine uygun edebiyat yapıtlarının önemi. İlköğretim Online, 15(4), 1399-1410.

Demirel, Ş. (2010). Edebi metinlerle çocuk edebiyatı. Ankara: Pegem Akademi.

Erdal, G. (2007). MEB yayınları çocuk kitaplarının resimlerine genel bakış. II. Ulusal Çocuk ve Gençlik Edebiyatı Sempozyumu. Ankara: AƯ Edebiyat Fakültesi. 
Göknil, C. (2006). Renk sihirbazları. Cumhuriyet Kitap, 935, İstanbul.

Gümüş, S. (1999). Öykünün bahçesi. İstanbul: Adam.

Karakoçan, M. (2007). Cemil Kavukçu'nun Hikayelerinde Yapı ve Tema İncelemesi. (Yayımlanmamış Yüksek Lisans Tezi). Fırat Üniversitesi Sosyal Bilimler Universitesi, Elazığ.

Karasar, N. (2020). Bilimsel araştırma yöntemi. Ankara: Nobel Akademik.

Kavukçu, C. (2019). Masal anlatma oyunu. İstanbul: Can Sanat (Can Çocuk).

Kavukçu, C. (2020). Bir öykü yazalım mı? İstanbul: Can Sanat (Can Çocuk).

Kaya, İ. (2007). Çocuk Kitabı Resimlerinde Estetik Boyut. II. Ulusal Çocuk ve Gençlik Edebiyatı Sempozyumu. Ankara: AÜ Edebiyat Fakültesi.

Kıbrıs, İ. (2010). Çocuk edebiyatı. Ankara: Kök.

Meriç, C. (1986). Kültürden irfana. İstanbul: İnsan.

Merriam, S. B. (2013). Nitel araştırma: desen ve uygulama için bir rehber. Selahattin Turan (Çev. Ed.). 3. Basımdan Çeviri. Ankara: Nobel.

Nas, R. (2004). Örneklerle çocuk edebiyatı. Bursa: Ezgi.

Oğuzkan, F. (2013). Çocuk edebiyatı. Ankara: Anı.

Özçelebi, H. (2011). Cemil Kavukçu'nun çocuk kitaplarına eleştirel bir bakış. Sedat Sever (Yay. Haz.). III. Ulusal Çocuk ve Gençlik Edebiyatı Sempozyumu Kitabı. (s. 453-461) Ankara: AÜ Eğitim Bilimleri Fakültesi.

Özer, A. (2007). Çocuk kitaplarındaki resimlerin çocuğa göreliği. II. Ulusal Çocuk ve Gençlik Edebiyatı Sempozyumu. Ankara: AÜ Edebiyat Fakültesi.

Özünel, Ş. Ç. (2000). Çocuk kitaplarındaki görsel anlatımın eğitimdeki önemi. I. Ulusal Çocuk Kitapları Sempozyumu. Ankara: Ankara Üniversitesi.

Sever, S. (2019a). Çocuk edebiyatı ve okuma kültürü. İzmir: Tudem.

Sever, S. (2019b). Çocuk ve edebiyat. İzmir: Tudem.

Sever, S. (1995). Çocuk kitaplarında bulunması gereken yapısal ve eğitsel özellikler. Abece Eğitim ve Ekin ve Sanat Dergisi, 107, 14-15.

Sever, S., Dilidüzgün, S., Neydim, N. ve Aslan, C. (2009). İlköğretimde çocuk edebiyatı. Eskişehir: Anadolu Üniversitesi.

Sümeyra, C. (2005). Son dönem Türk öykücülüğünde insan ve toplumsal hayat. Hece Öykü/Dosya: Seksen Sonrası Türk Öykücülüğ̈̈, 9, s. 69-75.

Şayak, G. (2011). Cemil Kavukçu'nun Öykülerinde İnsan. (Yayımlanmamış Yüksek Lisans Tezi). Yüzüncü Yıl Üniversitesi Sosyal Bilimler Üniversitesi, Van.

Şimşek, T. (2016). Kuramdan uygulamaya çocuk edebiyatı. Ankara: Grafiker.

Şirin, M. (2019). Çocuk edebiyatına eleştirel bir bakış. İstanbul: Uçan At.

Ural, S. (2013). Okul öncesi çocuk kitaplarının tanımı. M. Gönen (Ed.), Çocuk Edebiyatı (s.44-51). Ankara: Ertem Matbaas1.

Yalçın, A ve Aytaş, G. (2016). Çocuk edebiyatı (8.Basım). Ankara: Akçă̆.

Yıldırım, A. ve Şimşek, H. (2018). Sosyal bilimlerde nitel araştırma yöntemleri. Ankara: Seçkin. 